\title{
Aqueous phase processing of secondary organic aerosol from isoprene photooxidation
}

\author{
Y. Liu ${ }^{1,2, *}$, A. Monod ${ }^{1,2}$, T. Tritscher ${ }^{3, * *}$, A. P. Praplan ${ }^{3}$, P. F. DeCarlo ${ }^{3, * *}$, B. Temime-Roussel ${ }^{1,2}$, E. Quivet ${ }^{1,2}$, \\ N. Marchand ${ }^{1,2}$, J. Dommen ${ }^{3}$, and U. Baltensperger ${ }^{3}$ \\ ${ }^{1}$ Aix-Marseille Université, Laboratoire Chimie Environnement, 13331, Marseille cedex 03, France \\ ${ }^{2}$ CNRS, Laboratoire Chimie Environnement (FRE 3416), 13331, Marseille cedex 03, France \\ ${ }^{3}$ Paul Scherrer Institute (PSI), Laboratory of Atmospheric Chemistry, 5232, Villigen, Switzerland \\ *now at: LGEI, 6, avenue de Clavière, 30319, Alès, CEDEX, France \\ ***now at: TSI GmbH, Particle Instruments, Neuköllner Str. 4, 52068 Aachen, Germany \\ ${ }^{* * * *}$ now at: Drexel University, Dept. of Civil, Architectural, and Environmental Engineering, Philadelphia, PA 19104, USA
}

Correspondence to: A. Monod (anne.monod@univ-provence.fr)

Received: 22 July 2011 - Published in Atmos. Chem. Phys. Discuss.: 28 July 2011

Revised: 29 May 2012 - Accepted: 9 June 2012 - Published: 10 July 2012

\begin{abstract}
Transport of reactive air masses into humid and wet areas is highly frequent in the atmosphere, making the study of aqueous phase processing of secondary organic aerosol (SOA) very relevant. We have investigated the aqueous phase processing of SOA generated from gas-phase photooxidation of isoprene using a smog chamber. The SOA collected on filters was extracted by water and subsequently oxidized in the aqueous phase either by $\mathrm{H}_{2} \mathrm{O}_{2}$ under dark conditions or by $\mathrm{OH}$ radicals in the presence of light, using a photochemical reactor. Online and offline analytical techniques including SMPS, HR-AMS, H-TDMA, TD-API-AMS, were employed for physical and chemical characterization of the chamber SOA and nebulized filter extracts. After aqueous phase processing, the particles were significantly more hygroscopic, and HR-AMS data showed higher signal intensity at $m / z 44$ and a lower signal intensity at $m / z 43$, thus showing the impact of aqueous phase processing on SOA aging, in good agreement with a few previous studies. Additional offline measurement techniques (IC-MS, APCI-MS ${ }^{2}$ and HPLC-APCI-MS) permitted the identification and quantification of sixteen individual chemical compounds before and after aqueous phase processing. Among these compounds, small organic acids (including formic, glyoxylic, glycolic, butyric, oxalic and 2,3-dihydroxymethacrylic acid (i.e. 2methylglyceric acid)) were detected, and their concentrations significantly increased after aqueous phase processing. In particular, the aqueous phase formation of 2-methylglyceric
\end{abstract}

acid and trihydroxy-3-methylbutanal was correlated with the consumption of 2,3-dihydroxy-2-methyl-propanal, and 2-methylbutane-1,2,3,4-tetrol, respectively, and an aqueous phase mechanism was proposed accordingly. Overall, the aging effect observed here was rather small compared to previous studies, and this limited effect could possibly be explained by the lower liquid phase $\mathrm{OH}$ concentrations employed here, and/or the development of oligomers observed during aqueous phase processing.

\section{Introduction}

Secondary organic aerosol (SOA), formed by the chemical transformation of atmospheric organic compounds, accounts for a large, and often a dominant fraction of total organic aerosol (Hallquist et al., 2009; Jimenez et al., 2009). Detailed knowledge of the formation, characterization, and fate of SOA is required to evaluate its impact on atmospheric processes, climate and human health. The chemical characterization of SOA shows the presence of oxygenated and water soluble organic compounds such as carbonyl species, acids, esters, alcohols as well as polymers or oligomers (Hallquist et al., 2009 and references therein). The atmospheric oxidation of these organic particles affects the physical and chemical properties of aerosols through a process known as aging. The most recent studies on aging of organic 


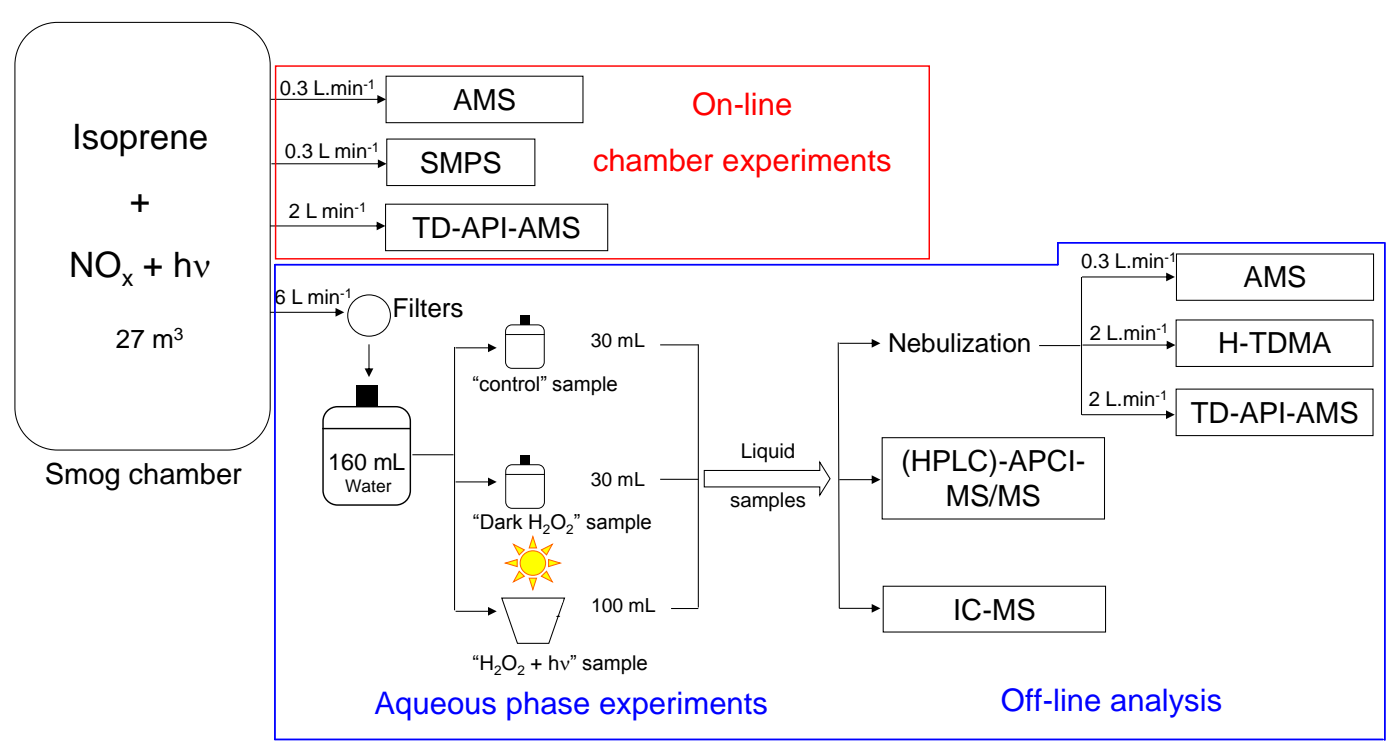

Fig. 1. General scheme of the experiments, including SOA formation in the smog chamber, particles sampling (on filters) and subsequent extraction in pure water, aqueous phase processing, and nebulization, together with the analytical instruments used to characterize the physical and chemical properties of the particles.

aerosol have focused on heterogeneous reactions, condensation, volatilization, as well as changes in hygroscopicity, oxygen to carbon atomic ratio ( $\mathrm{O}: \mathrm{C}$ ratio), and density (Rudich et al., 2007; Jimenez et al., 2009; Tritscher et al., 2011).

A fraction of the numerous organic compounds encountered in atmospheric water droplets (Kawamura and Sakaguchi, 1999; Sorooshian et al., 2007; Hua et al., 2008) is likely coming from both the gas phase and water dissolution of the organic matter present in the initial condensation nuclei (Hallquist et al., 2009; Ervens et al., 2011). Clouds continuously appear and disappear through evapo-condensation cycles, thus inducing continuous re-partitioning of organic compounds between the gas, aqueous, and particle phases. It is known that the reactivity of organic compounds can be very different in the aqueous phase compared to the gas phase (Altieri et al., 2006 and 2008; Carlton et al., 2007; Liu et al., 2009; El Haddad et al., 2009; Sun et al., 2010). Therefore, it is possible that the aging of SOA through evapocondensation cycles of clouds results in very different physical and chemical composition than the aging under dry conditions. A number of recent studies have focused on the ability of aqueous phase reactivity of some single organic compounds to form oligomers, and potentially new SOA (Altieri et al., 2006 and 2008; Carlton et al., 2006 and 2007; Perri et al., 2009; El Haddad et al., 2009; Tan et al., 2009 and 2010; Zhang et al., 2010; Liu et al., 2012; Ortiz-Montalvo et al., 2012). However, the effects of aqueous phase photooxidation of a complex mixture of organic compounds, such as those encountered in SOA, have only very recently been experimentally investigated by a few authors (Lee et al., 2011; Bateman et al., 2011; Nguyen et al., 2012) who have shown that this type of approach reveals a number of new aspects of SOA aging, that can be more atmospherically representative than the classical dry heterogeneous reactivity.

Although isoprene is the most abundant non-methane hydrocarbon emitted in the atmosphere, it was not considered as a significant contributor to SOA until recently. Nevertheless, some of its gas phase photooxidation products (such as methacrolein) are more direct precursors of SOA (Surratt et al., 2010; Lin et al., 2012), inducing isoprene photooxidation as one of the largest sources of atmospheric SOA (Hallquist et al., 2009; Carlton et al., 2009). Because most of the photooxidation products of isoprene are water soluble, it is likely that their aqueous phase processing has an important influence on SOA aging. Nguyen et al. (2012) investigated very recently UV irradiation of aqueous extracts of SOA generated from the photooxidation of isoprene. The aim of this work was to investigate the aqueous phase aging of isoprene SOA by photooxidation with $\mathrm{OH}$ radicals.

\section{Experimental section}

\subsection{General overview}

The aging of isoprene SOA during evapo-condensation cycles of a cloud was investigated under simulated conditions using a smog chamber and an aqueous phase photoreactor. Figure 1 illustrates the experimental set-up. SOA formed by the gas-phase photooxidation of isoprene was generated in the smog chamber, which was connected to on-line (SMPS, H-TDMA, HR-AMS, TD-API-AMS) and off-line (APCI$\mathrm{MS}^{2}$, HPLC-APCI-MS and IC-MS) measurement techniques 
(described below). For further liquid phase extraction and aqueous phase processing, large quantities of water soluble SOA were needed. Thus, high initial concentrations of isoprene (5.0 ppmv) under high $\mathrm{NO}_{\mathrm{x}}$ conditions $(1.25 \mathrm{ppmv}$ of $\mathrm{NO}$ and $\mathrm{NO}_{2}$, respectively) were used at $20-25^{\circ} \mathrm{C}$ and a relative humidity of 50-60\%. The formed particles were collected on Teflon filters at $61 \mathrm{~min}^{-1}$ during $2 \mathrm{~h}$ at the highest SOA concentrations (Supplement Fig. S1). The filters were extracted by sonication in $160 \mathrm{ml}$ of ultra-high quality (UHQ) water (Millipore). The extracted solution was then separated into three samples (Fig. 1): (1) " $\mathrm{H}_{2} \mathrm{O}_{2}+h v$ " sample: $100 \mathrm{ml}$ of the solution was placed in an aqueous phase photoreactor to undergo photooxidation with $\mathrm{OH}$ radicals during $20 \mathrm{~h}$. $\mathrm{OH}$ radicals were generated in situ by the photolysis of $\mathrm{H}_{2} \mathrm{O}_{2}$ $(0.1 \mathrm{M})$, which was added to the solution prior to photolysis. (2) "Dark $\mathrm{H}_{2} \mathrm{O}_{2}$ " sample: $\mathrm{H}_{2} \mathrm{O}_{2}(0.1 \mathrm{M})$ was added to $30 \mathrm{ml}$ of the extracted solution and kept in the dark during $20 \mathrm{~h}$, in order to compare the effects of $\mathrm{H}_{2} \mathrm{O}_{2}$ with those of $\mathrm{OH}$ radicals. (3) "control" sample: $30 \mathrm{ml}$ of the solution was left in the dark during the same time as the two other samples, in order to check for reactive changes of the untreated solution, compared to its reactivity towards $\mathrm{H}_{2} \mathrm{O}_{2}$ and/or OH radicals. In order to simulate a cloud evaporation process, each of the above-mentioned solution was then nebulized with an atomizer. The aerosol before and after the cloud simulation processes was analyzed with a suite of instruments as specified below. Two series of experiments were performed under these conditions.

\subsection{Chamber experiments}

The Paul Scherrer Institute smog chamber has been described in detail elsewhere (Paulsen et al., 2005). Briefly, it is a 27$\mathrm{m}^{3}$ Teflon bag $(3 \times 3 \times 3 \mathrm{~m})$ enclosed in a thermally regulated housing. The chamber is illuminated with four $4-\mathrm{kW}$ xenon arc lamps, to simulate the tropospheric solar spectrum. The lights are turned on after the gaseous precursors are equilibrated in the chamber (typically $15-30 \mathrm{~min}$ ). Experiments were monitored with a variety of aerosol and gas-phase characterization instruments, as outlined below. The experiments were conducted at $20-25^{\circ} \mathrm{C}$ and $50-60 \%$ relative humidity, and no seed particles were added.

\subsection{Aqueous phase experiments}

$\mathrm{OH}$-oxidation of the water extracts was performed in an aqueous phase photoreactor described in detail in Monod et al. (2005). Briefly, it is a PYREX thermo-controlled reactor of $450 \mathrm{~cm}^{3}$, equipped with a xenon arc lamp $(300 \mathrm{~W}$; Oriel), and a Pyrex filter to remove the UV irradiation below $300 \mathrm{~nm}$. The resulting irradiance spectrum was comparable to the one of the sun at the earth's ground level (in the UVvisible region), but much less intense (about $4 \%$ ). Hydrogen peroxide $(0.1 \mathrm{M})$ was added to the water extracts prior to photolysis, in order to produce $\mathrm{OH}$ radicals. The aqueous solution was continuously stirred and maintained at a constant temperature $(298 \pm 0.2 \mathrm{~K})$. The initial $\mathrm{H}_{2} \mathrm{O}_{2}$ concentration was chosen in order to produce sufficient quantities of $\mathrm{OH}$ radicals in the aqueous phase to oxidize the extracted organic compounds from the SOA. The initial concentration of $\mathrm{H}_{2} \mathrm{O}_{2}$ was calculated (i) using estimated values of the aqueous phase concentrations of soluble organic compounds; (ii) assuming for them an aqueous phase $\mathrm{OH}$-oxidation rate constant similar to the one of methacrolein (Liu et al., 2009); (iii) in order to favour the $\mathrm{OH}$-oxidation of soluble organics rather than that of $\mathrm{H}_{2} \mathrm{O}_{2}$ by a factor of more than $70 \%$ (under the above assumptions).

\subsection{Nebulization experiments}

Liquid solutions were nebulized using a TSI 3076 type nebulizer, and an experimental set up described in details in Paulsen et al. (2006). The particle laden air out of the nebulizer, with a flow of $\sim 1.51 \mathrm{~min}^{-1}$, was diluted by synthetic air with a flow of $\sim 1.51 \mathrm{~min}^{-1}$ from a gas bottle or a pure air generator (AADCO Instruments, Inc., USA, 737-250 series). The resulting flow was then driven through a stainless steel tube, before entering the online analysers, i.e. the HR-AMS, the H-TDMA and the TD-API-AMS (described below). For the experiments described here, the "control", "dark $\mathrm{H}_{2} \mathrm{O}_{2}$ " and " $\mathrm{H}_{2} \mathrm{O}_{2}+h v$ " samples were nebulized during at least $90 \mathrm{~min}$.

\subsection{Analysis}

\subsubsection{On-line aerosol characterization}

The physical and chemical characterization of the SOA was performed online in the smog chamber using an SMPS, an H-TDMA, an HR-AMS and a TD-API-AMS and after their aqueous phase processing and subsequent nebulization, using the same H-TDMA, HR-AMS and TD-API-AMS (Fig. 1). The number size distribution was measured with a scanning mobility particle sizer (SMPS) consisting of a differential mobility analyzer (DMA, TSI 3071) and a condensation particle counter (CPC, TSI 3022A).

The custom built H-TDMA selects a dry, narrow size fraction of the aerosol $\left(\mathrm{DMA}_{1}\right)$, humidifies it at high relative humidity (RH $90 \%$ ) and scans the conditioned aerosol with a second DMA (DMA $)$ and a CPC (TSI 3022A). The used instrument is described in Tritscher et al. (2011). From the measured size distribution, a hygroscopic growth factor for a certain RH is calculated. The H-TDMA data were calibrated, analyzed and inverted with the TDMAinv procedure from Gysel et al. (2009). Measured dry particle diameters ranged from $35-150 \mathrm{~nm}$ during the nebulizer experiments. To exclude the Kelvin effect, we present the data in the form of the hygroscopicity parameter kappa $(\kappa)$ (Petters and Kreidenweis, 2007), assuming the surface tension of pure water. 
This parameter $\kappa$ ranges from 0 for insoluble but wettable material to ca. 1.4 for very hygroscopic salts.

A high resolution time-of-flight aerosol mass spectrometer (HR-AMS, Aerodyne) (DeCarlo et al., 2006) was used to measure online the bulk chemical composition of the nonrefractory submicron particulate matter. Data was saved every two minutes during smog chamber experiments and during nebulization.

Further on-line analysis of the chemical composition of SOA was performed using a modified version of a commercial (Varian 1200L) atmospheric pressure chemical ionization device, equipped with a triple quadrupole mass spectrometer (APCI-MS ${ }^{2}$ ). The inlet of this instrument had been modified to transform it into an aerosol mass spectrometer, named TD-API-AMS, as described and validated by Eyglunent et al. (2008). Briefly, the modified inlet consists of a charcoal denuder (to trap gas phase VOCs and SVOCs) followed by a modified thermal-desorption unit (held at $300^{\circ} \mathrm{C}$ ) attached to the APCI source. The aerosol was injected at a flow rate of $21 \mathrm{~min}^{-1}$. In order to optimize the ionization, liquid methanol $\left(10 \mu \mathrm{min}^{-1}\right)$ was continuously vaporized in the air stream containing the volatilized organic aerosol prior to ionization by a corona discharge. The intensity of the corona discharge was set at $9 \mu \mathrm{A}$ and the shield voltage at $600 \mathrm{~V}$. The analyses were performed using alternatively the positive and the negative ionization modes with a capillary voltage of $+40 \mathrm{~V}$ and $-40 \mathrm{~V}$, respectively. Nitrogen served both as the drying gas and the auxiliary gas and was delivered at a pressure of $1.0 \times 10^{5}$ and $1.4 \times 10^{4} \mathrm{~Pa}$, respectively. The drying gas temperature was held at $350{ }^{\circ} \mathrm{C}$. The total ion current (TIC) of the mass spectra were recorded between 65 and 1000 Dalton (Da) for the negative mode, and between 59 and $1000 \mathrm{Da}$ for the positive mode during the analysis, with a resolution of $1.0 \mathrm{Da}$ and a scan time of $5 \mathrm{~s}$. This instrument is complementary to the HR-AMS as the atmospheric pressure chemical ionization is a soft ionization method resulting in minimal fragmentation, and thus it allows one to determine the molar mass of most of the compounds present in the mixture. In positive ionization, ions are produced by protonation with $\mathrm{H}^{+}$or cationization with sodium ions $\mathrm{Na}^{+}$, present in all glasswares, and in particular in the syringe bringing methanol into the air stream), leading to $[\mathrm{M}+1]^{+}$ or $[\mathrm{M}+23]^{+}$ions for most oxygenated compounds. The negative ionization mode leads to the formation of deprotonated ions $[\mathrm{M}-1]^{-}$and gives a response primarily for species bearing an acidic hydrogen.

\subsubsection{Aqueous phase characterizations}

The chemical composition of liquid samples before and after $20 \mathrm{~h}$ of reaction with $\mathrm{OH}$, or $\mathrm{H}_{2} \mathrm{O}_{2}$, or untreated, was analyzed by an atmospheric pressure chemical ionization mass spectrometer operated with either a direct infusion of the solutions (APCI-MS), or with a liquid chromatographic sepa- ration column (HPLC-APCI-MS), and ion chromatography coupled to a mass spectrometer (IC-MS).

Direct analysis of the liquid samples was performed using the APCI-MS and APCI-MS ${ }^{2}$ (Varian 1200L) Samples and standard solutions were directly infused into the APCI source (no chromatographic column) at a flow rate of $40 \mu \mathrm{min}^{-1}$. In order to optimize the ionization of organic molecules, liquid methanol $\left(0.2 \mu \mathrm{min}^{-1}\right)$ was continuously vaporized into the APCI source using an HPLC pump. The nebulizing gas was nitrogen for the positive mode and synthetic air for the negative mode, delivered at a pressure of $55 \mathrm{psi}$ at $300^{\circ} \mathrm{C}$. All other parameters (i.e. voltages, pressures and temperatures of drying and auxiliary gases, corona discharge intensity and voltage, mass range, resolution and scan time) were set at the same conditions as those indicated above for the TD-APIAMS analyses. The compounds were identified by APCI$\mathrm{MS}^{2}$ characterization. In this case, argon (collision gas) was delivered at a pressure of $0.27 \mathrm{~Pa}$ to the collision cell. The collision energy was between 5 and $20 \mathrm{~V}$ depending on the compound, with a resolution of $1.0 \mathrm{Da}$ and a scan time of $0.5 \mathrm{~s}$.

Liquid samples were also analyzed by HPLC-APCI-MS. The separation column was a Synergi $4 \mathrm{u}$ Hydro-RP $250 \times$ $2 \mathrm{~mm}, 4 \mu \mathrm{m}$, Phenomenex. The analytes were subjected to chromatography using a gradient of two solvents (A: $0.1 \%$ acetic acid aqueous solution and B: methanol) delivered at a constant flow rate of $0.2 \mathrm{ml} \mathrm{min}^{-1}$. The elution program was: $5 \%$ of B from 0 to $12 \mathrm{~min}$, then increased linearly to $100 \%$ from $12 \mathrm{~min}$ to $60 \mathrm{~min}$, followed by $100 \%$ of B from 60 to $65 \mathrm{~min}$, and $5 \% \mathrm{~B}$ until $90 \mathrm{~min}$. The analyses were realized using selected ion monitoring (SIM) in the positive and in the negative mode. The APCI parameters were the same as described above with a resolution of $1.0 \mathrm{Da}$ and a scan time of $0.5 \mathrm{~s}$.

Liquid samples were also analyzed by IC-MS, in order to detect the organic acids present in the extracts. The samples were directly injected onto a separation column (AS11-HC with a guard column AG-11HC, Dionex) where they were eluted within $29 \mathrm{~min}$ with a hydroxy anion $\left(\mathrm{OH}^{-}\right)$gradient: $0 \min 0.5 \mathrm{mM} \mathrm{OH}^{-}, 5 \min 0.5 \mathrm{mM}, 15 \min 20 \mathrm{mM}, 21 \min$ $60 \mathrm{mM}, 23 \mathrm{~min} 60 \mathrm{mM}, 23.1 \mathrm{~min} 0.5 \mathrm{mM}, 29 \mathrm{~min} 0.5 \mathrm{mM}$. After elution, the $\mathrm{OH}^{-}$was eliminated by an anion selfregenerating suppressor (ASRS ${ }^{\circledR}$ Ultra $2 \mathrm{~mm}$, Dionex). The detector was a mass spectrometer coupled with an electrospray ionization source (ESI-MS) operated in the negative mode, with a capillary voltage of $3.5 \mathrm{kV}$ and a source voltage of $50 \mathrm{~V}$. The nebulizing gas was held at $450^{\circ} \mathrm{C}$. The carboxylic acids were identified by their $m / z$ values and their retention times (RT), by comparison to commercially available standards.

\subsection{Reagents}

Isoprene (Fluka 99.5\%), $\mathrm{H}_{2} \mathrm{O}_{2}$ (without stabilizer, Aldrich, $50 \mathrm{wt} \%$ ), glyoxylic acid (Acros, 98\%), pyruvic acid 
(Aldrich, 98\%), oxalic acid (Sigma-Aldrich, $\geq 99 \%$ ), 3butene-1,2-diol (Aldrich, $\geq 99 \%$ ), D-erythrose (Sigma, $\geq$ $75 \%$ ), DL-glyceraldehyde (ABCR, $40 \%$ in water), Dthreitol (Aldrich, 99\%), 2-methylfuran (Aldrich, 99\%), 3-methylcrotonaldehyde (Aldrich, 97\%), and methanol (Acros, HPLC grade) were used. Following the protocol described by Claeys et al. (2004b), 2,3-dihydroxymethacrylic acid, which is often called 2-methylglyceric acid (2-MG) was synthesized from methacrylic acid (Acros, $99.5 \%$ ) by reaction with hydrogen peroxide ( $50 \%$ aqueous solution; $50 \mathrm{ml}$ ), in the presence of sulfuric acid $(0.1 \mathrm{M} ; 25 \mathrm{ml})$. The $\mathrm{pH}$ of the mixture was around 2 . The reaction mixture was shaken thoroughly and left at room temperature for $2 \mathrm{~h}$ before analysis. A detailed identification of this molecule by mass spectrometry can be found in Liu et al. (2009). The synthesis of 1-hydroxyethyhydroperoxide (1-HEHP) was performed by mixing pure acetaldehyde $(6 \mu \mathrm{l})$ and $\mathrm{H}_{2} \mathrm{O}_{2}(50 \%$ aqueous solution; $8 \mu \mathrm{l}$ ) in $10 \mathrm{ml}$ of pure water during five days prior to analysis. Solutions were prepared using ultra high quality (UHQ) water (Millipore), including reverse osmosis, micro-filtration, nuclear-grade deionization and activated carbon modules. The resistivity of the obtained water was greater than $1.8 \times 10^{7} \Omega \mathrm{cm}$.

\section{Results and discussion}

\subsection{SOA formation in the smog chamber}

Substantial quantities of SOA were formed in the smog chamber during the gas phase photooxidation of isoprene (Fig. S1). The particle size distribution, as measured by the SMPS, showed a very good agreement between experiments 1 and 2 (Fig. S1), while their number concentration was slightly lower for experiment 2 : the maximum number concentration was $33.3( \pm 0.4) \times 10^{3}$ particle $\mathrm{cm}^{-3}$ for experiment 1 , while it was $27.7( \pm 0.2) \times 10^{3}$ particle $\mathrm{cm}^{-3}$ for experiment 2. Maximum SOA concentrations were $1150( \pm 35)$ and $1010( \pm 30) \mu \mathrm{g} \mathrm{m}^{-3}$ for experiments 1 and 2 respectively, as measured by the HR-AMS. They were collected for $2 \mathrm{~h}$ at $61 \mathrm{~min}^{-1}$ on a Teflon filter and then extracted in $160 \mathrm{ml}$ UHQ water. Taking into account these numbers together with the aerosol mass concentrations in the smog chamber during sampling, the expected aqueous phase concentration of organic aerosol, after water extraction, was in the range 3$4 \mathrm{mg}^{-1}$ for both experiments (detailed calculation is in Supplement S1). These organic concentrations in the extracts are similar to dissolved organic mass (DOM) concentrations found in bulk precipitation $\left(0.5-5.0 \mathrm{mg}^{-1}\right)$ at Zagreb and Sibenik, Croatia (Orlovic-Leko et al., 2009) and to those found in cloud water (1-9 mg $1^{-1}$ ) at Puy de Dome, France (Marinoni et al., 2004).

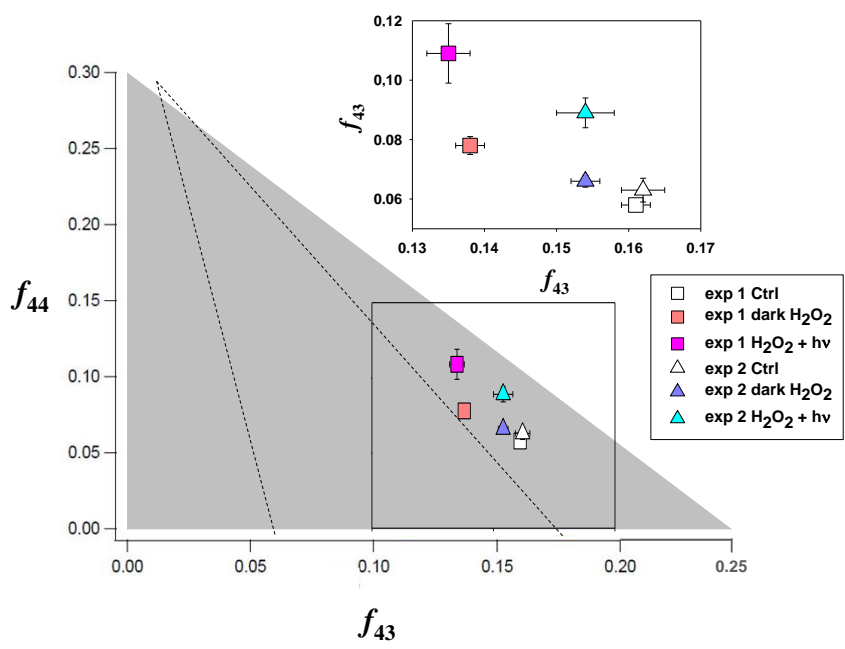

Fig. 2. $f_{44}$ versus $f_{43}$ for LV-OOA and SV-OOA components from a compilation of ambient air data (dotted line area) ( $\mathrm{Ng}$ et al., 2010) and simulation chamber data (grey area) (Lee et al., 2011), and from the two isoprene experiments measured in this work (and the corresponding zoom). Error bars represent the standard deviation for the first 44 min of nebulization for "control" samples (Ctrl), "dark $\mathrm{H}_{2} \mathrm{O}_{2}$ " samples, and " $\mathrm{H}_{2} \mathrm{O}_{2}+h v$ " samples.

\subsection{Influence of aqueous phase processing on SOA ag- ing: global physical and chemical characterizations (HR-AMS and H-TDMA measurements)}

The bulk composition as measured by the HR-AMS showed a slightly higher $f_{44}$ (ratio of $m / z 44$ to total organic aerosol) for the water extracted organic aerosol than from the direct chamber measurement. This is in very good agreement with the observations by Lee et al. (2011) who performed the same kind of SOA treatment and analysis, and is potentially due to the loss of less soluble species having lower extraction efficiency than more oxidized species. The degree of oxidation can be characterized in terms of the two dominant ions $m / z 44\left(\mathrm{CO}_{2}^{+}\right)$and $m / z 43$ (mostly $\mathrm{C}_{2} \mathrm{H}_{3} \mathrm{O}^{+}$), which were used to follow the aging of organic aerosol in the atmosphere by a compilation study of AMS data (Ng et al., 2010). In this study, low volatility oxygenated organic aerosol (LV-OOA) has a higher $f_{44}$ component compared to the semi-volatile oxygenated organic aerosol (SV-OOA) which in turn has a higher $f_{43}$ (ratio of $m / z 43$ to total organic aerosol). Figure 2 compares the $f_{44}$ versus $f_{43}$ values to those provided in the compilation by $\mathrm{Ng}$ et al. (2010), and the results obtained by Lee et al. (2011). It is seen that the $f_{44}$ versus $f_{43}$ values obtained here fall close to the lower half of the triangular region defined by $\mathrm{Ng}$ et al. (2010). This region of the triangle is characteristic of lower $\mathrm{O}: \mathrm{C}$ ratios and photochemical ages, and is the region where most of the laboratory SOA data are found ( $\mathrm{Ng}$ et al., 2010; Lee et al., 2011). Figure 2 shows that $f_{43}$ decreases and $f_{44}$ increases in " $\mathrm{H}_{2} \mathrm{O}_{2}+h v$ " samples compared to "control" samples, thus 


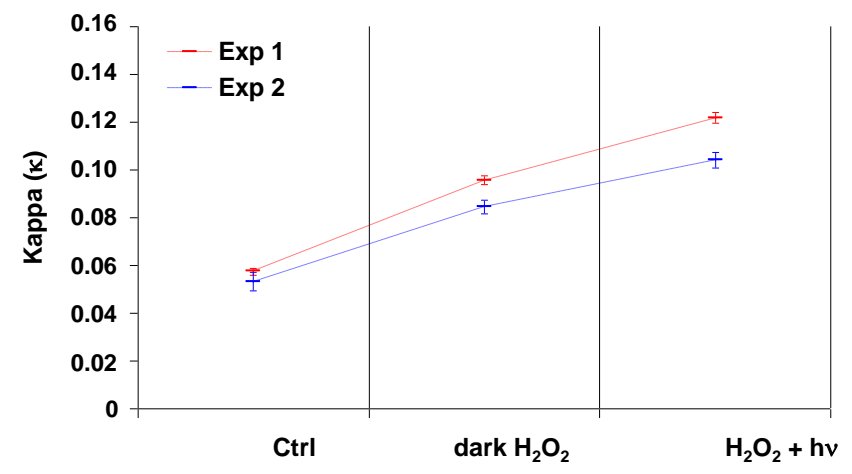

Fig. 3. Hygroscopicity parameter kappa $(\kappa)$ measured during nebulization of "control" samples (Ctrl), "dark $\mathrm{H}_{2} \mathrm{O}_{2}$ " samples (dark $\left.\mathrm{H}_{2} \mathrm{O}_{2}\right)$ and " $\mathrm{H}_{2} \mathrm{O}_{2}+h v$ " samples $\left(\mathrm{H}_{2} \mathrm{O}_{2}+h v\right)$ for the two isoprene experiments. The $\kappa$ values were measured from hygroscopic growth factor data (HGF, for $50 \mathrm{~nm}$ dry particle diameters). Error bars represent the standard deviations during $90 \mathrm{~min}$ of nebulization.

showing SOA aging induced by aqueous phase photooxidation. Moreover, $f_{44}$ values of our " $\mathrm{H}_{2} \mathrm{O}_{2}+h v$ " samples move towards the values of LV-OOA observed in the field by $\mathrm{Ng}$ et al. (2010). These observations are in very good agreement with the results of Lee et al. (2011) who investigated aqueous $\mathrm{OH}$ oxidation of (i) glyoxal, (ii) mixtures of glyoxal with $\alpha$-pinene SOA components (iii) ambient biogenic SOA, and (iv) cloud water from a biogenic environment. Our results are also in good agreement with those of Bateman et al. (2011) and Nguyen et al. (2012) who investigated UV irradiation of aqueous extracts of SOA generated from the dark ozonolysis of d-limonene and from the photooxidation of isoprene (with high $\mathrm{NO}_{\mathrm{x}}$ conditions), respectively. The aging effect obtained here, as measured by the $f_{44}$ increase (by a factor of 1.4-1.9) is of the same order of magnitude (factor of 1.2-1.9) as the ones obtained during gas phase photooxidation of isoprene by $\mathrm{Ng}$ et al. (2010), Chhabra et al. (2011) and Duplissy et al. (2011), and is slightly lower than the ones (factor 1.9-2.2) obtained by Lee et al. (2011) after aqueous phase processing of ambient fresh and aged biogenic SOA, and biogenic cloud water. This difference can be due to different aqueous phase concentrations of $\mathrm{OH}$ radicals (estimated to be $10^{-15}$ $5 \times 10^{-15} \mathrm{M}$ in our study, and $10^{-13}-10^{-12} \mathrm{M}$ in Lee et al., 2011 ), and it can also be due to aqueous phase oligomerization processes observed in the present study (see Sect. 3.4).

The dependence of the hygroscopicity on particle composition can be represented with the hygroscopicity parameter $\kappa$. According to Petters and Kreidenweis (2007), the values of $\kappa$ range from 0.01 to 0.5 for slightly to very hygroscopic organic species. The $\kappa$ values obtained here for "control" samples were comprised between 0.05 and 0.06 , thus showing that the formed SOA was only slightly hygroscopic (Fig. 3). The hygroscopicity of the particles increased significantly from "control" samples $(\kappa=0.05-0.06)$ to "dark $\mathrm{H}_{2} \mathrm{O}_{2}$ " samples $(\kappa=0.06-0.10)$ and to " $\mathrm{H}_{2} \mathrm{O}_{2}+h v$ " sam- ples $(\kappa=0.10-0.13)$. This increase of hygroscopicity indicates that the aged SOA (after aqueous phase processing) contained more hygroscopic products. This result is consistent with the HR-AMS data which showed a clear increase of the $f_{44} / f_{43}$ ratio from "control" samples to " $\mathrm{H}_{2} \mathrm{O}_{2}+h v$ " samples. These observations of the bulk aerosol hygroscopic properties provide evidence for SOA aging through aqueous phase photooxidation. Comparing the two experiments, Fig. 3 shows that, although both experiments start at the same values of $\kappa$ (for both selected particle diameters), the aqueous phase aging effect is significantly more pronounced for experiment 1 than for experiment 2 . The reason for this more pronounced aging effect is difficult to explain since the two experiments have been performed under the same conditions. The major difference is that filter sampling (from the smog chamber) started one hour later for the first experiment than for the second one. Meanwhile, the more pronounced aging effect in experiment 1 is in excellent agreement with the HRAMS results (Fig. 2). Figure 4 shows a linear dependency between $\kappa$ and $f_{44}$ (which can be converted into $\mathrm{O}: \mathrm{C}$ ratio using the relationship established by Aiken et al., 2008) in good agreement with the studies of Chang et al. (2010), Massoli et al. (2010), Duplissy et al. (2011) and Lambe et al. (2011) who investigated a large panel of gas-phase SOA precursors including alkanes, aromatics, terpenes and isoprene, but also field samples collected at different types of sites (urban, elevated, rural...). Comparing our "control" samples with the smog chamber data obtained by Duplissy et al. (2011) during isoprene photooxidation (performed under similar conditions as ours), we observed a shift of the kappa values to higher values in our study (Fig. 4). This increase in hygroscopicity (with constant $f_{44}$ values) may be due to water extraction of SOA and subsequent nebulization carried out in our study, while Duplissy et al. (2011) performed direct measurements in the smog chamber. Meanwhile, the slope obtained here (Fig. 4) (1.75 \pm 0.25$)$ is in very good agreement with the ones obtained by Duplissy et al. (2011) (who selected $\kappa$ values measured under similar conditions as here, i.e. obtained from hygroscopic growth factors - HGF) for gas-phase smog chamber aging of biogenic SOA $(2.02 \pm 0.04)$ and also for field data (Jungfraujoch and Mexico city: $2.2 \pm 0.4$ ). These observations show that, compared to gas-phase aging, aqueous phase aging of biogenic SOA did not substantially modify the correlations between the hygroscopicity (derived from HGF) and oxidation levels of biogenic SOA. Finally, the good agreement between our slope and those obtained for the field data selected by Duplissy et al. (2011) from Mexico City and Jungfraujoch, is encouraging.

\subsection{Influence of sampling, extraction and/or nebulization on the chemical composition of SOA}

The mass spectra obtained using the TD-API-AMS directly connected to the smog chamber showed a large number of ions in both the negative and the positive modes (Fig. 5). 


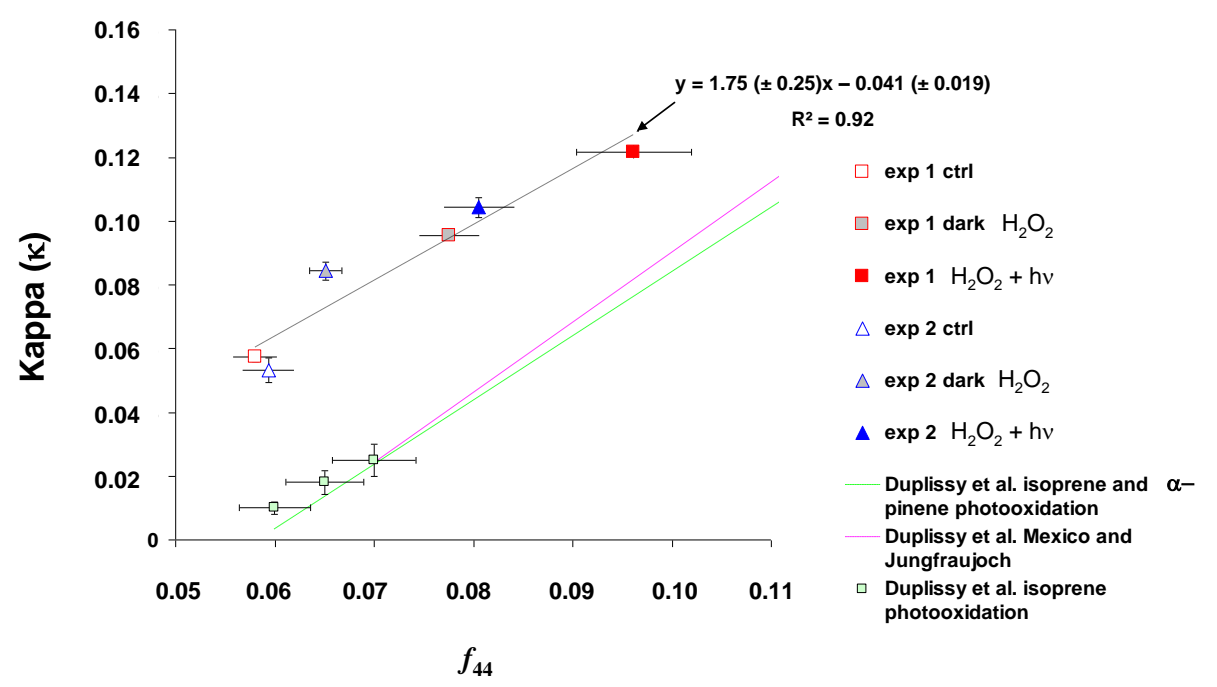

Fig. 4. Relationship between $f_{44}$ (obtained from HR-AMS measurements) and $\kappa$ (obtained from H-TDMA measurements) for experiments 1 and 2 during nebulization of "control", "dark $\mathrm{H}_{2} \mathrm{O}_{2}$ " and " $\mathrm{H}_{2} \mathrm{O}_{2}+h v$ " samples, obtained after aqueous phase processing of SOA formed from isoprene photooxidation. Comparisons with previous smog chamber and field data obtained by Duplissy et al. (2011). Error bars are the same as those indicated in Figs. 2 and 3.

The most abundant ions in both modes were observed in the mass range 75-250 Da with some ions present up to $260 \mathrm{Da}$. Above $300 \mathrm{Da}$, no ions were observed under our instrumental conditions. As mentioned earlier, due to the low fragmentation generated in this instrument, the ions detected provide the molar mass of most of the compounds present in the mixture. However, compared to earlier studies, we observed substantially less large oligomers. In isoprene SOA, there is a prominent pattern in the mass spectra based on 2,3dihydroxy-methacrylic acid (often called 2-methylglyceric acid, 2-MG), leading to a repeated difference of $102 \mathrm{Da}$, up to $\sim 600$ Da due to its polyesterification (Edney et al., 2005; Dommen et al., 2006; Surratt et al., 2006; Szmigielski et al., 2007; Nguyen et al., 2011). Figure 5 shows qualitatively that we detected the corresponding monomers and some of the dimers, but nothing higher. Several reasons can explain these differences: (i) large oligomers $(>300 \mathrm{Da})$ were observed in previous studies at both low $\mathrm{RH}(<5 \%)$ and high $\mathrm{RH}$ (50 or $90 \%$ ), but they were more intense at low RH (Nguyen et al., 2011), thus, under our conditions $(\mathrm{RH}=50-60 \%)$, the expected signal was low; (ii) large oligomers were previously observed after several pre-concentration steps (using organic solvents), which was impossible to perform in our on-line system, nor in our "control" samples.

In order to investigate the effects of sampling, extraction and nebulization on the chemical composition of SOA, Fig. 5 shows a comparison of the mass spectra obtained by (i) direct on-line measurements from the chamber, and (ii) measurements of the nebulized solutions of "control" samples. The ion intensity of the nebulized aerosols is significantly lower than the ones from the chamber, by a factor of 2.2 in the negative mode, and 3.0 in the positive mode. These fac- tors were determined by linear regressions of the intensity of the major masses (most intense peaks) between the measurements from the smog chamber and the measurements after nebulization of "control" samples (Fig. S2). On-line and offline measurements were well correlated $\left(R^{2}=0.88\right.$ and 0.82 for negative and positive modes, respectively), with a slight shift between the ratios obtained for the positive mode (3.0) compared to the negative mode (2.2). This shift was possibly due to more efficient water extraction of organic acids (which were mostly detected in the negative mode, see next section), in good agreement with the slight shift in $f_{44}$ observed with the HR-AMS, and the shift observed in the $\kappa$ value, as measured by the H-TDMA. Overall, all the analytical devices indicated that relatively more soluble compounds (such as acids) were present in the water extracts, compared to the SOA composition.

\subsection{Influence of aqueous phase processing on SOA aging: individual chemical characterizations in the aqueous phase}

In order to investigate the effects of aqueous phase processing on the chemical composition of the sampled SOA through oxidation by $\mathrm{H}_{2} \mathrm{O}_{2}$ in the dark or oxidation by $\mathrm{OH}$ radicals, comparisons between the chemical composition of (i) "control" samples and " $\mathrm{H}_{2} \mathrm{O}_{2}+h v$ " samples (Fig. 6); (ii) "control" sample and "dark $\mathrm{H}_{2} \mathrm{O}_{2}$ " samples (Fig. S3); (iii) "dark $\mathrm{H}_{2} \mathrm{O}_{2}$ " samples and " $\mathrm{H}_{2} \mathrm{O}_{2}+h v$ " sample (Fig. S4) were performed. The mass spectra, obtained by direct infusion into the APCI-MS ${ }^{2}$, showed significant differences. Many new compounds were formed during the aqueous phase processing, as seen by the appearance of new 

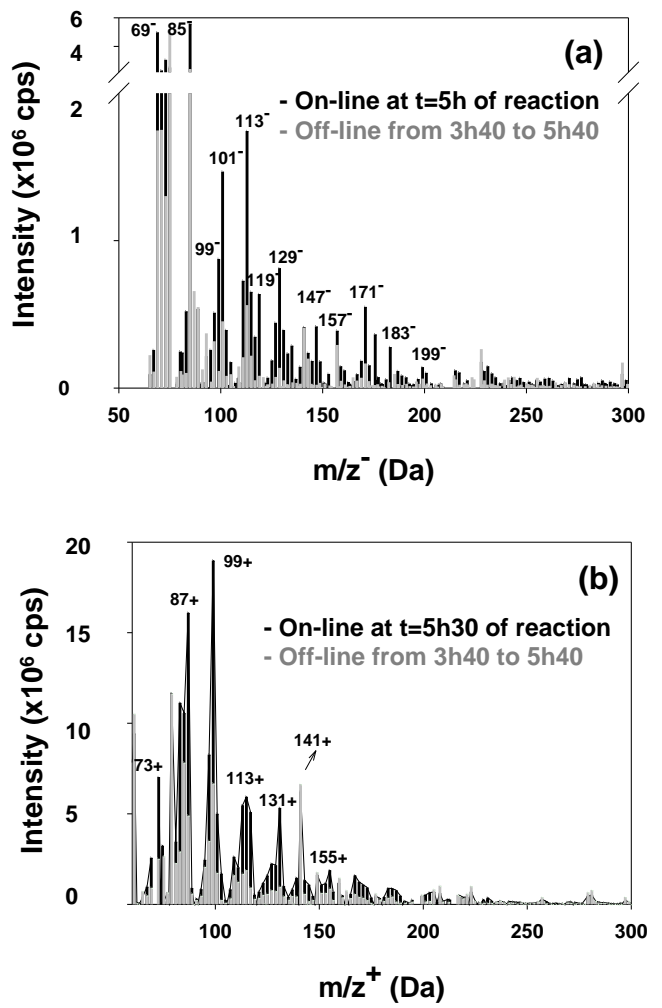

Fig. 5. TD-API-AMS measurements (a) in the negative mode and (b) in the positive mode of the chemical composition of SOA formed during isoprene photooxidation (experiment 1). Comparison of the mass spectra obtained (i) by direct on-line measurement in the smog chamber (in black), and (ii) by nebulization of "control" samples (in grey).

ions, principally in the negative mode, in two distinct mass ranges: $60-150 \mathrm{Da}$, and $150-300 \mathrm{Da}$ (Fig. 6). By comparing the " $\mathrm{H}_{2} \mathrm{O}_{2}+h v$ " samples with the "dark $\mathrm{H}_{2} \mathrm{O}_{2}$ " samples and "control" samples (Fig. S3 and S4), it becomes clear that the formation of these ions in these two mass ranges were caused by both $\mathrm{OH}$ radicals and $\mathrm{H}_{2} \mathrm{O}_{2}$. The negative values of the mass spectra differences (i.e. products consumption) are not presented because they showed fewer (less than 10) and much less intense peaks (by a factor of 2 to 8 ). As these comparisons are only qualitative, a detailed study of the chemical composition of aqueous samples was performed. The identification of reaction products was done in " $\mathrm{H}_{2} \mathrm{O}_{2}+h v$ " samples, using APCI-MS ${ }^{2}$ during experiment 1. Additionally, in order to determine the effects of aqueous phase processing on SOA composition, the abundance of 16 identified products was compared between " $\mathrm{H}_{2} \mathrm{O}_{2}+h v$ " samples, "dark $\mathrm{H}_{2} \mathrm{O}_{2}$ " samples and "control" samples using HPLC-APCI-MS and IC-MS during experiment 2. The results obtained using these complementary analyses are discussed in the following, for the mass ranges $60-150 \mathrm{Da}$ and 150-300 Da successively.
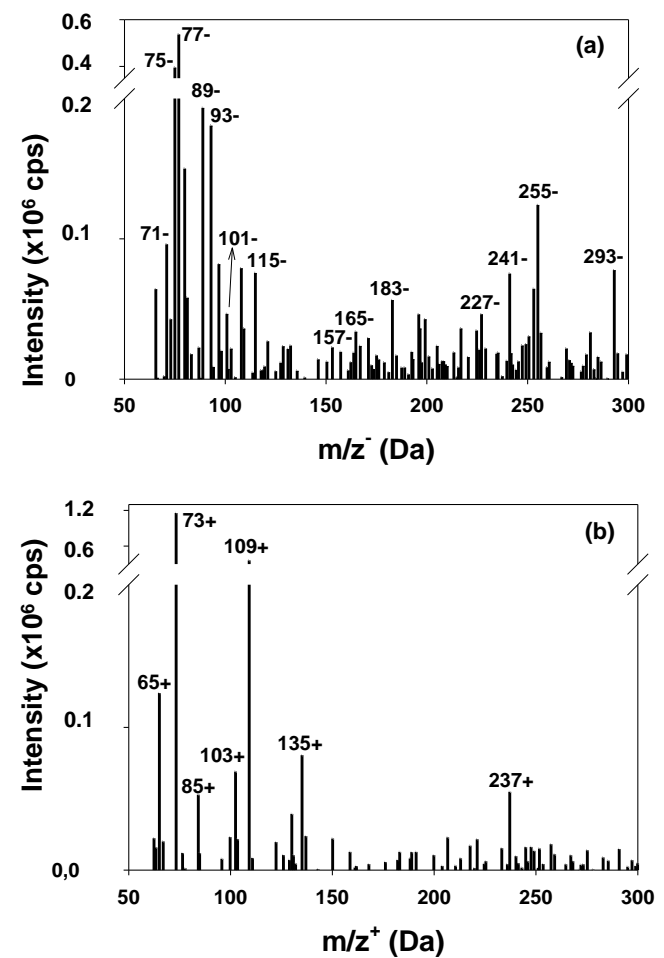

Fig. 6. Mass spectra (in the negative mode a and in the positive mode b) differences between " $\mathrm{H}_{2} \mathrm{O}_{2}+h v$ " samples and "control" samples which show the ions formed during the aqueous phase processing (experiment 1), measured with APCI-MS by direct infusion of aqueous solutions.

\subsubsection{Influence of aqueous phase processing on the for- mation of reaction products in the mass range 60-150 Da}

Figure 6 shows that in the mass range $60-150 \mathrm{Da}$, most of the formed products have ion masses corresponding to those observed in the initial SOA (Fig. 5). It is thus likely that the aqueous phase aging of SOA induces an amplification of the formation of the corresponding products. Further identification and quantification of sixteen of these aqueous phase products confirms this assumption. The identification was performed by comparison of the APCI-MS ${ }^{2}$ fragments between " $\mathrm{H}_{2} \mathrm{O}_{2}+h v$ " samples and of commercial or synthesized standards with exact or similar chemical structures (Table 1). We identified 2-methylbut-3-ene-1,2diol (MB-diol), 2,3-dihydroxy-2-methyl-propanal (DHMP), trihydroxy-3-methylbutanal (THMB), 2-methylbutane1,2,3,4-tetrol (tetrol) in the negative mode using commercial standards that had the same chemical structure except for a methyl group. The obtained mass spectra were similar, with a systematic shift of $14 \mathrm{Da}$ corresponding to the missing methyl group in the standards. We identified 3methylfuran (3-MF) and 3-methylbut-3-enal (MB-3-enal) in the positive mode with commercial standard isomers. 
Table 1. Identification and quantification of reaction products (experiments 1 and 2), in the mass range 60-150 Da.

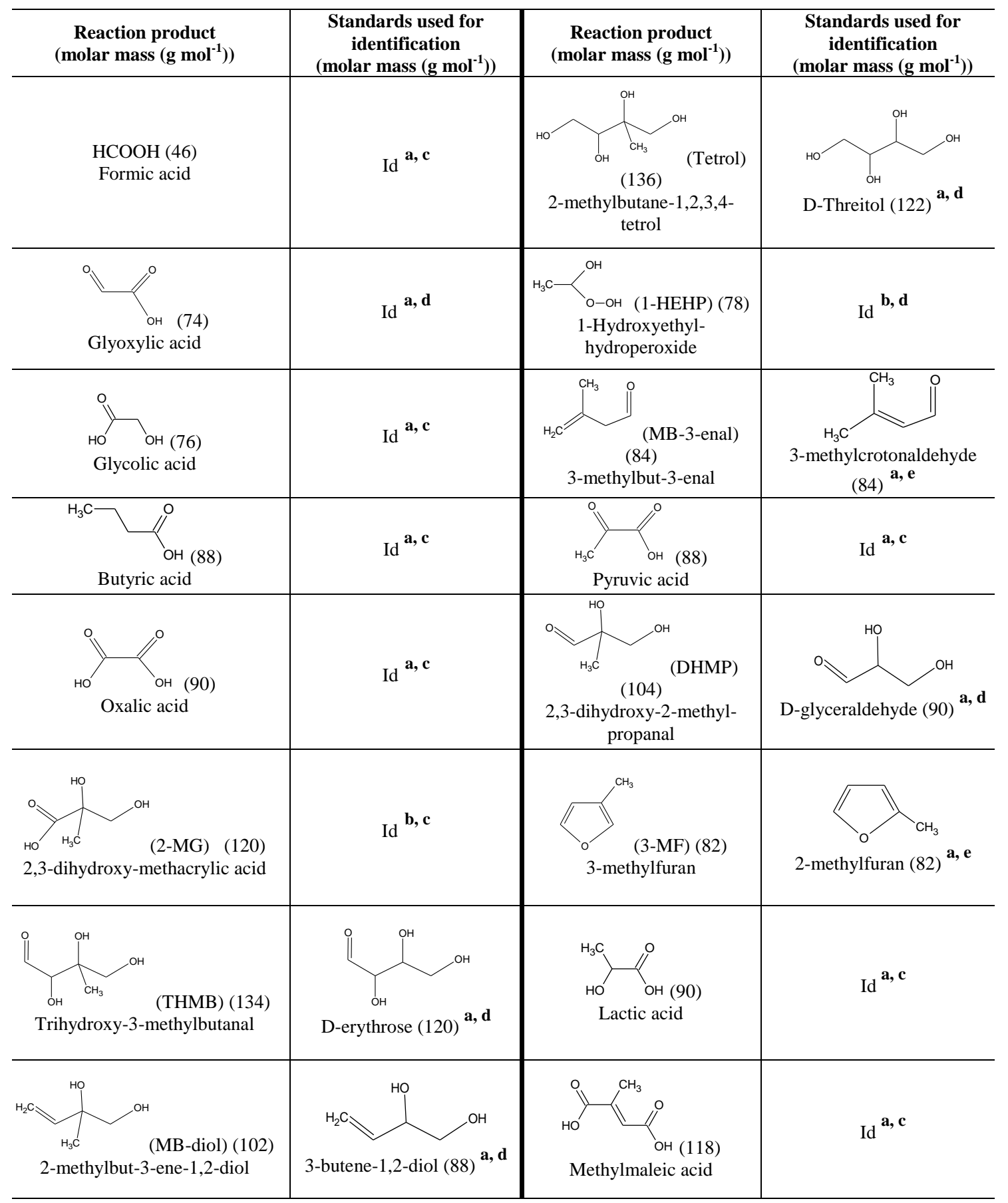

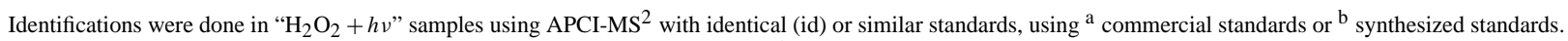
Quantifications as shown in Figs. 7 and S5 were performed using ${ }^{\mathrm{c}}$ IC-MS, using ${ }^{\mathrm{d}}$ HPLC-APCI-MS in the negative mode or using ${ }^{\mathrm{e}}$ HPLC-APCI-MS in the positive mode.

Finally, 1-hydroxyethyl-hydroperoxide (1-HEHP) and 2,3dihydroxy-methacrylic acid (often called 2-methylglyceric acid, 2-MG) were identified using synthesized standards (see Section on reagents). Some of these identified reaction products (such as tetrol, 2-MG, oxalic, glyoxylic and pyruvic acids) were identified in isoprene SOA in earlier studies
(Claeys et al., 2004a; Edney et al., 2005; Dommen et al., 2006; Surratt et al., 2006; Szmigielski et al., 2007; Sato, 2008; Nguyen et al., 2011). MB-diol and THMB were identified during liquid phase (photo)oxidation of isoprene in the presence of high concentrations of $\mathrm{H}_{2} \mathrm{O}_{2}$ (Silva Santos et al., 2006). Others, such as DHMP, glycolic, lactic and 

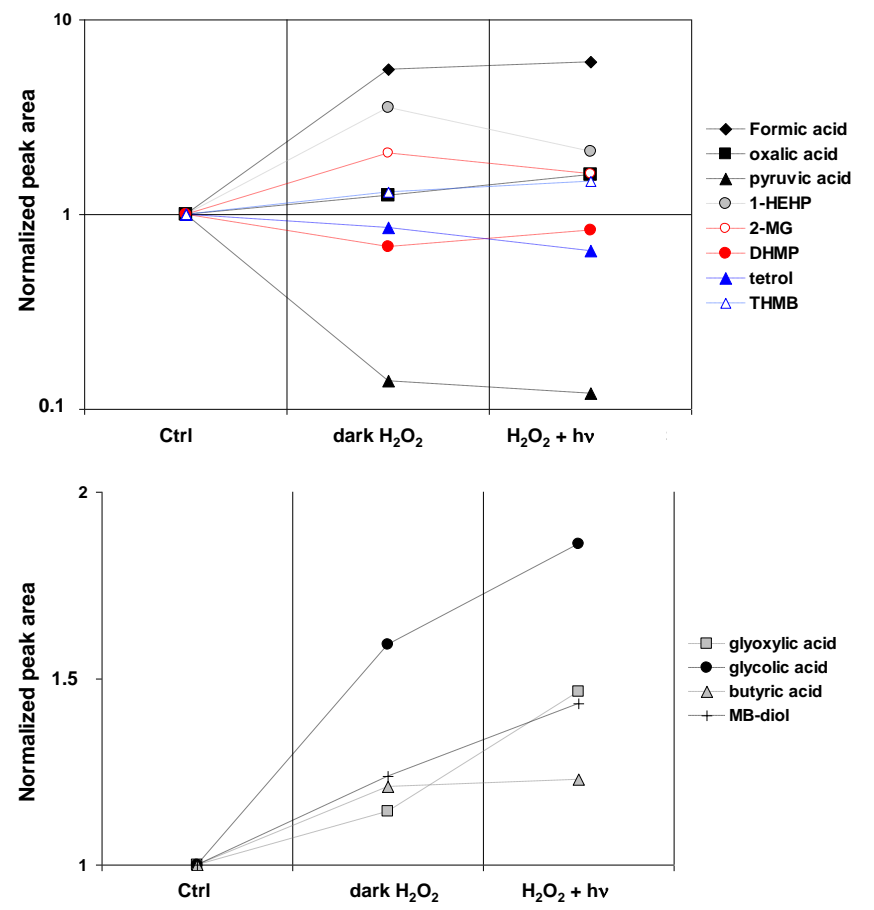

Fig. 7. Evolution of 12 identified and quantified reaction products from "control", "dark $\mathrm{H}_{2} \mathrm{O}_{2}$ " to " $\mathrm{H}_{2} \mathrm{O}_{2}+h v$ " samples in the mass range $60-120 \mathrm{Da}$ (experiment 2). All peak areas were normalized to "control" samples. 1-HEHP =1-hydroxyethylhydroperoxyde; $2-\mathrm{MG}=32$ 2,3-dihydroxy-methacrylic acid (often called 2methylglyceric acid); DHMP = 2,3-dihydroxy-2-methyl-propanal; Tetrol = 2-methylbutane-1,2,3,4-tetrol; $\quad$ THMB = Trihydroxy-3methylbutanal; MB-diol=2-methylbut-3-ene-1,2-diol. Quantification was performed using 35 the conditions indicated in Table 1 where the corresponding chemical structures are indicated.

methylmaleic acids were found in other types of SOA, but were observed here in isoprene SOA for the first time (to our knowledge). Their formation pathways need to be further elucidated. Finally, some of our identified reaction products are so volatile $\left(P_{\mathrm{sat}}>10^{-3} \mathrm{~atm}\right)$ (such as formic, butyric acids, 1-HEHP, 3-methylfuran, 3-methylbut-3-enal), that they should theoretically be present only in the gas phase even at our high total SOA mass concentrations (i.e. $\sim 1000 \mu \mathrm{g} \mathrm{m}^{-3}$ ) (Valorso et al., 2011). It is probable that some of these observed volatile compounds (especially the acids) came from the polyesters known to form in isoprene SOA (by particle-phase esterification, i.e. Surratt et al., 2006), by the reverse pathway of esterification during water extraction.

Finally, it can be noted that most of the observed compounds are particularly atmospherically relevant as they have also been observed as constituents of atmospheric SOA in rural and/or forested area (Claeys et al., 2004a) and water droplets in a power plant plume, as well as in clouds (Kawamura and Sakaguchi, 1999; Sorooshian et al., 2006 and 2007).
During experiment 2, HPLC-APCI-MS and IC-MS measurements were performed for the liquid samples in order to compare the quantity of the sixteen identified compounds between " $\mathrm{H}_{2} \mathrm{O}_{2}+h v$ " samples, "dark $\mathrm{H}_{2} \mathrm{O}_{2}$ " samples and "control" samples (Figs. 7 and S5). The HPLC-APCI-MS and IC-MS techniques allowed separating species that had the same molecular mass and for a quantitative comparison between the three samples, which is much more precise than the direct infusion method. Because no systematic calibration was performed for all these compounds, and because the analyses of the three samples were performed under the same conditions, the chromatographic peak areas (which were proportional to the aqueous phase concentrations under our experimental conditions) are compared in Figs. 7 and S5. All peak areas were normalized to the "control" sample. The analytic standard deviation was 3 to $14 \%$ for HPLC-APCI-MS, and varied from 1 to $25 \%$ for IC-MS, depending on the species and their concentrations. Among the sixteen compounds, the concentrations of nine compounds (i.e. formic, glyoxylic, glycolic, butyric, oxalic acid, 2-MG, THMB, MB-diol, MB-3-enal) increased significantly in the " $\mathrm{H}_{2} \mathrm{O}_{2}+h v$ " samples and "dark $\mathrm{H}_{2} \mathrm{O}_{2}$ " samples compared to the "control" samples (Figs. 7 and S5). It is thus likely that these compounds were produced in the aqueous phase by oxidation of water soluble precursors by $\mathrm{H}_{2} \mathrm{O}_{2}$ and/or by photooxidation. Their potential precursors in the aqueous phase are small multifunctional carbonyls (glycolaldehyde, hydroxyacetone, glyoxal, methylglyoxal, hydroxymethylglyoxal, oxopropanedial, 2,3-dioxobutanal), which could not be detected under our instrumental conditions, and have been identified by Healy et al. (2008) on SOA formed from isoprene photooxidation in smog chambers under similar conditions as ours. All these precursors are highly water soluble, thus they were likely transferred to the aqueous phase in our experiments, and were then oxidized. The aqueous phase photooxidation of glycolaldehyde (studied by Perri et al., 2009 and Ortiz-Montalvo et al., 2012) leads to the formation of glyoxal, but also to glycolic, glyoxylic and oxalic acids which concentrations increased from the "control" to the " $\mathrm{H}_{2} \mathrm{O}_{2}+h v$ " samples in the present study (Fig. 7). The formation of glyoxylic and oxalic acids has also been observed during the aqueous phase photooxidation of methylglyoxal (Altieri et al., 2008 and Tan et al., 2010) and glyoxal (Carlton et al., 2007 and Tan et al., 2009), which are among the potential precursors identified in isoprene SOA by Healy et al. (2008). The aqueous phase photooxidation of the other precursors (i.e. hydroxyacetone, hydroxymethylglyoxal, oxopropanedial and 2,3-dioxobutanal) has not yet been studied (to our knowledge), but is likely to produce the acids that were observed to increase in the present study from the "control" to the " $\mathrm{H}_{2} \mathrm{O}_{2}+h v$ " samples. Overall, most of the acids identified here increased with aqueous phase processing, in good agreement with the increase of the $f_{44}$ value (measured with the HR-AMS after nebulization) which is a major fragment of organic acids. It can be noted that formic 
and oxalic acids are among those acids showing the largest increase, which is in good agreement with the fact that these compounds are end chain reaction products and are stable towards most of reactants in the atmosphere, as shown by field observations (Legrand and Puxbaum, 2007; Sorooshian et al., 2006 and 2007).

For pyruvic acid, DHMP and tetrol, a significant decrease of their concentrations was observed between the "control" sample and the " $\mathrm{H}_{2} \mathrm{O}_{2}+h v$ " sample, and between the "control" samples and "dark $\mathrm{H}_{2} \mathrm{O}_{2}$ " samples, indicating that they were consumed by oxidation by $\mathrm{H}_{2} \mathrm{O}_{2}$ and photooxidation. For pyruvic acid, this observation is in agreement with the studies by Guzmán et al. (2006), Carlton et al. (2006) and Altieri et al. (2006) who showed that in the aqueous phase pyruvic acid is photosensitive and highly reactive towards $\mathrm{OH}$ radicals, leading to the formation of oxalic acid (among other products), which has been observed to increase accordingly with aqueous phase processing in the present study.

The concentration of 1-HEHP showed a particular behaviour: it increased significantly in the "dark $\mathrm{H}_{2} \mathrm{O}_{2}$ " and " $\mathrm{H}_{2} \mathrm{O}_{2}+h v$ " samples compared to "control" sample, and it decreased significantly from the "dark $\mathrm{H}_{2} \mathrm{O}_{2}$ " to the " $\mathrm{H}_{2} \mathrm{O}_{2}+h v$ " samples. This behaviour can be explained by the dissolution of larger carbonyl and/or gemdiol compounds, followed by $\mathrm{H}_{2} \mathrm{O}_{2}$ oxidation in the dark, leading to the formation of hydroperoxides such as 1-HEHP, and by further $\mathrm{OH}$ oxidation and/or direct photolysis of 1-HEHP (which is highly photosensitive as shown by Monod et al., 2007) in the " $\mathrm{H}_{2} \mathrm{O}_{2}+h v$ " sample.

The concentrations of 3-methylfuran did not show any significant changes between "control" sample, "dark $\mathrm{H}_{2} \mathrm{O}_{2}$ " sample and " $\mathrm{H}_{2} \mathrm{O}_{2}+h v$ " sample. The reason for this behaviour may be that this compound was produced and consumed in the aqueous phase in roughly the same quantities.

Among the compounds that were produced in the aqueous phase, 2-MG and THMB correspond to the oxidized forms of DHMP and tetrol, respectively, which were consumed in the aqueous phase: their respective evolutions in the three samples were remarkably symmetric (coloured symbols in Fig. 7). It is thus probable that the aqueous phase oxidation of DHMP and tetrol by $\mathrm{H}_{2} \mathrm{O}_{2}$ and/or by $\mathrm{OH}$ radicals leads to 2MG and THMB, respectively, following the chemical mechanisms proposed in Fig. 8a and b. In particular, the decrease of tetrol (Fig. 7) by photooxidation during $20 \mathrm{~h}$ allowed us to calculate an aqueous phase life time of $46 \mathrm{~h}$ under our experimental conditions. It can be noted that under higher aqueous phase concentrations of $\mathrm{OH}$ radicals than in our study (typically $1-5 \times 10^{-13} \mathrm{M}$ ), this life time can decrease down to $1 / 2 \mathrm{~h}$. In field studies, tetrol is known as a marker compound of isoprene SOA (Claeys et al., 2004a and b). As this compound is highly water soluble, it is likely to spend a few hours in the liquid phase during air mass transport where it can be consumed leading to THMB. In order to avoid an underestimation in the amounts of isoprene SOA in the atmosphere, one should take into account the quantities of both tetrol and its reaction product THMB.

Overall, the aging effects observed here due to $\mathrm{H}_{2} \mathrm{O}_{2}$ oxidation (in the dark) were generally comparable to those due to aqueous phase photooxidation ( $\mathrm{OH}$ radicals). These observations can be explained by the amounts of $\mathrm{H}_{2} \mathrm{O}_{2}$ used here (which are comparable to those used by Lee et al. (2011), but 2 to 3 orders of magnitude higher than in atmospheric waters), which were necessary to produce relevant amounts of $\mathrm{OH}$ radicals, estimated at $10^{-15}-5 \times 10^{-15} \mathrm{M}$, corresponding to typical concentrations in urban cloud droplets (Anastasio and McGregor, 2001; Herrmann et al., 2010).

\subsubsection{Influence of aqueous phase processing on the formation of oligomers observed in the mass range 150-300 Da}

In the mass range $150-300 \mathrm{Da}$, most of the ions were new (Fig. 6) compared to the initial SOA composition (Fig. 5). Their molecular masses were 2 to 4 times higher than that of isoprene, and the observed distribution was consistent with the development of an oligomer system that shows a highly regular pattern of mass differences of 14, 16, 18 and $28 \mathrm{Da}$. We assume that the corresponding products have been formed by aqueous phase oligomerization processes, as the same type of pattern was observed during aqueous phase photooxidation of methacrolein (Liu et al., 2009). In the mass range $150-300 \mathrm{Da}$, we focused our analyses on five ions (at $m / z=153^{+}, 169^{-}, 171^{-}, 183^{-}$and $233^{-} \mathrm{Da}$ ), which showed significant changes during aqueous phase processing as observed through HPLC-APCI-MS analyses. These five ions had different retention times (between 5.5 and $7 \mathrm{~min}$ for $\mathrm{m} / z=169^{-}, 171^{-}, 153^{+} \mathrm{Da} ; 42 \mathrm{~min}$ for $\mathrm{m} / z=$ $183^{-} \mathrm{Da}$, and $64 \mathrm{~min}$ for $\mathrm{m} / z=233^{-} \mathrm{Da}$ ) and could thus be attributed to different reaction products. These five compounds were further characterized using APCI-MS/MS fragmentation (Fig. 9). Neutral losses of 18, 28, 30 and 46 indicates that ion $153^{+}$could be a hydroxyl-carbonyl compound; the neutral losses of 28,30 and 44 indicate that the ions $169^{-}$, $183^{-}$and $233^{-}$can be oxo-carboxylic acids; and the neutral losses of 18 and 44 indicate that the ion $171^{-}$can be a hydroxy-carboxylic acid or a dicarboxylic acid.

Some of the potential precursors (glycolaldehyde, glyoxal, methylglyoxal, pyruvic acid) of the low weight mass reaction products observed in the mass range $60-150 \mathrm{Da}$ (Sect. 3.4.1) have been shown to produce oligomers through aqueous phase photooxidation (Altieri et al., 2006 and 2008; Carlton et al., 2006 and 2007; Perri et al., 2009; El Haddad et al., 2009; Tan et al., 2009 and 2010; Zhang et al., 2010; Liu et al., 2012; Ortiz-Montalvo et al., 2012). Despite the very good agreement of the present study with previous works concerning the formation of low weight mass polyfunctional compounds through aqueous phase photooxidation of these potential precursors (Sect. 3.4.1), the oligomer formation seems to behave very differently. Comparing the most intense peaks 
(a)

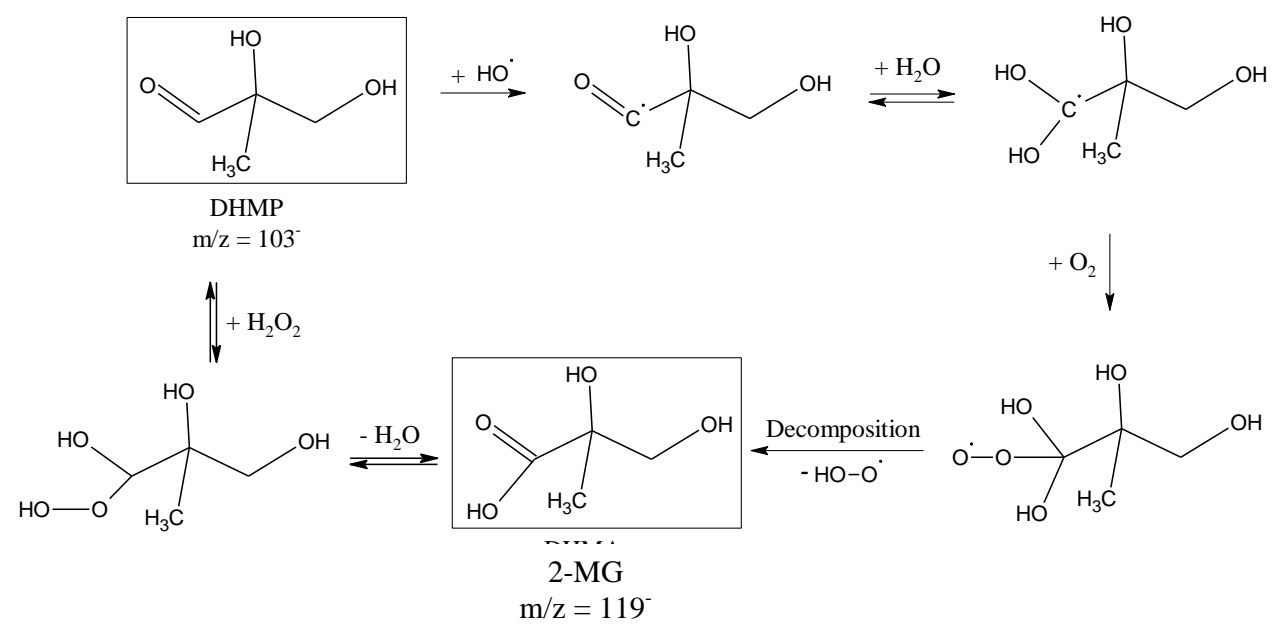

(b)

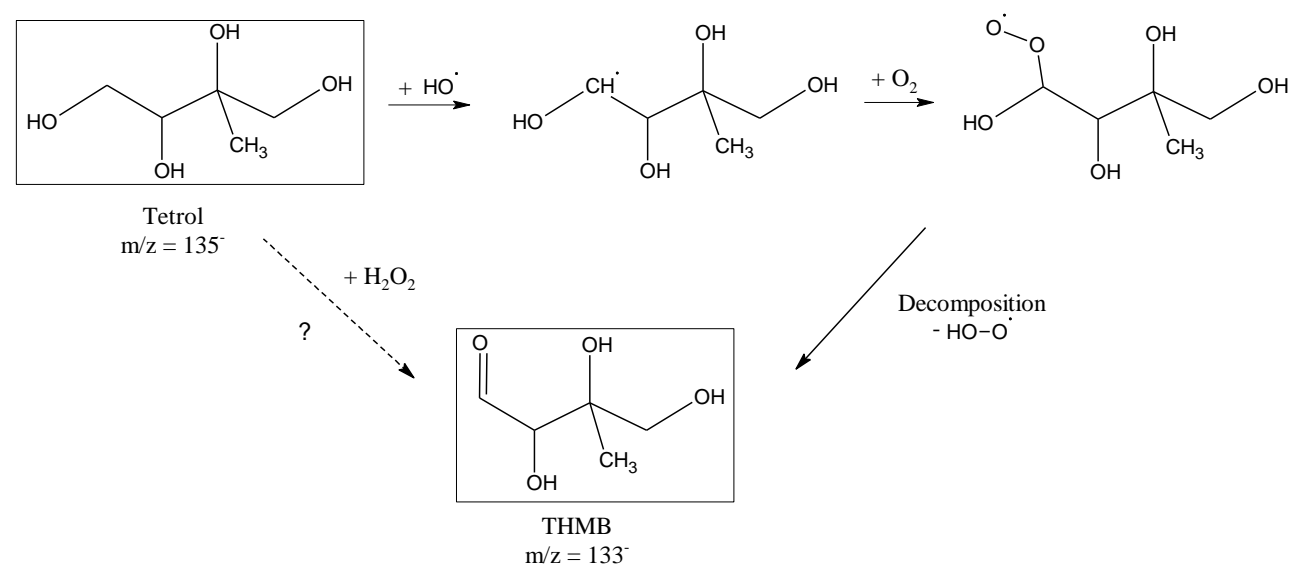

Fig. 8. Chemical mechanism of aqueous phase oxidation by $\mathrm{H}_{2} \mathrm{O}_{2}$ and by $\mathrm{OH}$ radicals of (a) 2,3-dihydroxy-2-methyl-propanal (DHMP) leading to 2,3-dihydroxy-methacrylic acid (2-14 MG); and (b) 2-methylbutane-1,2,3,4-tetrol (tetrol) leading to trihydroxy-3-methylbutanal (THMB).

of the mass spectra obtained in the present study (above $150 \mathrm{Da}$ ) with those described in the literature, no concordance was achieved except for two ions:

- At 171 Da in the negative mode: the fragmentation spectrum obtained for this ion was very similar to the one obtained by El Haddad et al. (2009) (with the same instrument, operated under the same conditions) during the aqueous phase $\mathrm{OH}$ oxidation of methacrolein, at $20 \mathrm{~h}$ of reaction (Fig. 9). However, methacrolein (one of the major gas-phase reaction products of isoprene) is highly volatile, and was not present in the initial SOA. It is thus likely that ion $171^{-}$is a reaction product formed in the aqueous phase from the photooxidation of common non-volatile products of methacrolein and isoprene.

- At 233 Da in the negative mode: this ion has been observed by Perri et al. (2009) and by Altieri et al. (2008), during the aqueous phase photooxidation of glycolaldehyde and methylglyoxal, respectively. It was attributed to an oligomeric series consisting of the addition of oxalic acid to $n$ molecules of methylglyoxal (with $n=2$ in the case of ion $\mathrm{m} / \mathrm{z} 233^{-}$). However, the fragmentation of $233^{-}$in the present study (Fig. 9) does not reveal the presence of a subunit 72 (i.e. methylglyoxal). It is thus probable that ion $233^{-}$does not correspond to the same oligomer system as the one described by Perri 

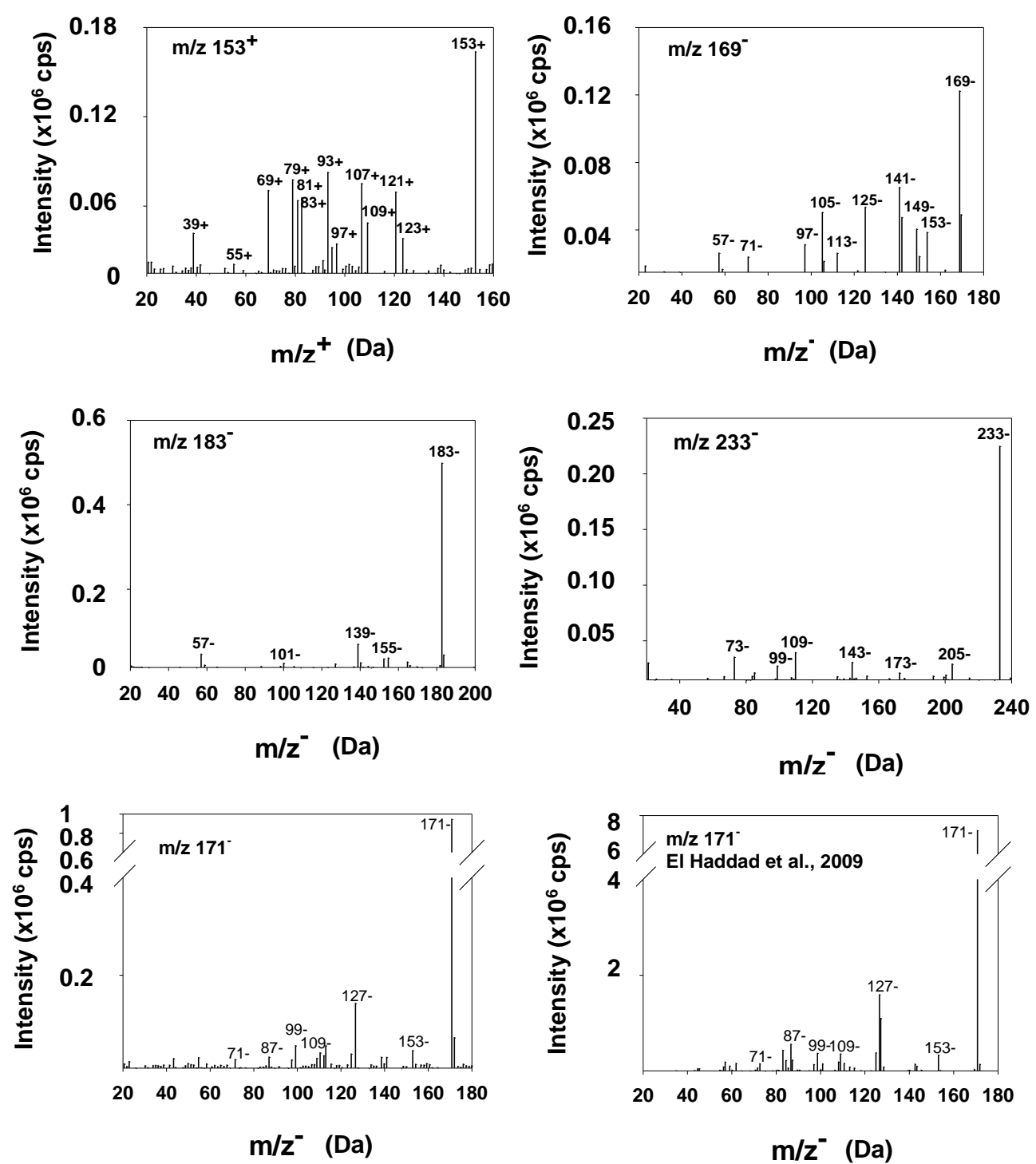

Fig. 9. APCI-MS2 spectra of five reaction products observed in " $\mathrm{H}_{2} \mathrm{O}_{2}+h v$ sample after isoprene photooxidation (exp. 2) in the mass range $150-300 \mathrm{Da}$. The fragmentation spectrum obtained for $m / z=171^{-}$(collision energy $=10 \mathrm{eV}$ ) is compared to the one obtained by El Haddad et al. (2009) during the aqueous phase photooxidation of methacrolein (collision energy $=8 \mathrm{eV}$ ) (at $20 \mathrm{~h}$ of reaction), which is one of the major gas-phase reaction products of isoprene.

et al. (2009), and Altieri et al. (2008) and revisited by Ortiz-Montalvo et al. (2012) and by Tan et al. (2012), respectively.

These observations may indicate that the oligomerization process was very different in the present study compared to previous aqueous phase studies. If we compare our results more globally with the aqueous phase literature dealing with oligomers, we can say that we have observed large differences of mass spectral patterns (in terms of recurrent mass differences and highest mass) which can be explained by the difference in the initial conditions. In the present study, we investigated aqueous phase processing of a complex mixture containing a low initial concentration of dissolved organic matter (DOM) of 3-4 $\mathrm{mg}^{-1}$ (Sect. 3.1), whereas the previous studies investigated aqueous phase photooxidation of a single oxygenated compound at elevated initial concentrations, ranging from 17 to $1800 \mathrm{mg} \mathrm{l}^{-1}$, thus 5 to 500 times more concentrated than in our study. It is probable that our reactive complex mixture contained several aqueous phase oligomer precursors, thus explaining why we obtained here different oligomers at the much lower initial reactants concentrations compared to all previous aqueous phase studies dealing with oligomer formation. 


\section{Conclusions}

We report experimental results on the aging of isoprene SOA by photooxidation in the aqueous phase. After sampling and water extraction of SOA formed in a smog chamber, the expected liquid phase concentration of organic matter (calculated from the SOA mass measured in the smog chamber and the quantity sampled and extracted in water) was in the range of DOM concentrations found in bulk precipitation and in cloud water.

The results show that aqueous phase processing induces a significant aging of isoprene SOA. Comparing the nebulized SOA before and after aqueous phase processing (by $\mathrm{H}_{2} \mathrm{O}_{2}$ oxidation, and by photooxidation) the particles were significantly more hygroscopic, and contained increased $f_{44}$ in the HR-AMS spectrum after aqueous phase processing. The hygroscopicity of the SOA was measured after aqueous phase processing for the first time (to our knowledge). The corresponding $\kappa$ values (derived from HGF) showed a high correlation with $f_{44}$ values, and the obtained slope was in good agreement with previous laboratory and field studies on biogenic SOA. Comparing these results with previous aqueous phase aging studies, it seems that the aging of SOA (as depicted by the $f_{44}$ values and/or the O/C ratios) due to aqueous phase processing occurs independent of the SOA precursor: it was seen from the ozonolysis of d-limonene (Bateman et al., 2011), from the ozonolysis of $\alpha$-pinene (Lee et al., 2011), from the photooxidation of isoprene (this work, and also Nguyen et al., 2012), and finally from atmospheric aerosols and cloud water collected in a coniferous forest mountain site (Lee et al., 2011). Furthermore, we have shown that this aqueous phase aging of SOA induced a significant increase of the quantities of nine compounds, including formic, glyoxylic, glycolic, butyric, oxalic and 2-methylglyceric acids, trihydroxy-3-methylbutanal, 2-methylbut-3-ene-1,2-diol and 3-methylbut-3-enal. In particular, the aqueous phase formation of 2-methylglyceric acid and trihydroxy-3-methylbutanal were correlated with the consumption of 2,3-dihydroxy-2-methyl-propanal, and 2-methylbutane-1,2,3,4-tetrol, respectively, and an aqueous phase chemical mechanism was proposed accordingly.

However, the aging effect observed here was small compared to other studies: $f_{44}$ values barely reached the LV-OOA values, and globally, the aging effects due to aqueous phase $\mathrm{H}_{2} \mathrm{O}_{2}$ oxidation (in the dark) were comparable to those due to aqueous phase photooxidation ( $\mathrm{OH}$ radicals). These observations could be explained by the amounts of $\mathrm{H}_{2} \mathrm{O}_{2}$ used here (which were comparable to those used by Lee et al. (2011), but 2 to 3 orders of magnitude higher than in atmospheric waters), and by the aqueous phase $\mathrm{OH}$ concentrations (estimated at $10^{-15}-5 \times 10^{-15} \mathrm{M}$ ) which were lower than in previous aqueous phase studies, and fell in the low range of the atmospherically relevant ones. The formation of oligomers (which limits the $f_{44}$ increase with aging) found here during aqueous phase processing of isoprene SOA could be another explanation to the limited aging effect observed.

The aqueous phase oligomer development seems to depend on the photochemical system, and specifically the presence of OH radicals. Nguyen et al. (2012) investigated the aging of very similar isoprene SOA (obtained from isoprene $(500 \mathrm{ppb})$ photooxidation under high $\mathrm{NO}_{\mathrm{x}}$ concentrations $(800 \mathrm{ppb}))$, which they irradiated without any $\mathrm{OH}$ precursor addition. They observed depleted oligomer concentrations in their processed SOA (compared to gas-phase SOA), while in the presence of aqueous phase $\mathrm{OH}$-radicals (even at low concentrations) we observed an enrichment of the oligomers in our processed SOA. This confirms that, at least in the case of isoprene SOA, aqueous phase $\mathrm{OH}$ chemistry leads to polymerization of organics, whereas photolysis leads to fragmentation.

Furthermore, our results suggest that not only the initial concentration, but also the initial composition has an important impact on the development of oligomers in the aqueous phase. Studies investigating aqueous phase processing of one single oligomer precursor reported oligomerization when the initial concentration of the precursor was higher than 14 to $72 \mathrm{mg} \mathrm{l}^{-1}$ (Tan et al., 2009, 2010; Liu et al., 2012). In the present study, we observed oligomer formation during aqueous phase processing with an initial DOM concentration as low as $3-4 \mathrm{mg} \mathrm{l}^{-1}$, containing a complex mixture of organics including many oligomer precursors (such as pyruvic acid). It is thus likely that the initial composition plays a crucial role on the oligomerization processes in the aqueous phase, and more generally on SOA aging.

Transport of air masses to humid and/or wet areas is highly frequent in the atmosphere, making the study of aqueous phase processing particularly relevant. The present study confirms the conclusions of very few previous studies on the fact that the aqueous phase processing induces aging of organic particles. However, it also shows that different liquid phase conditions (photolysis, concentrations of $\mathrm{OH}$ radicals, initial DOM composition and concentrations etc.) can lead to different aging aspects. Therefore, more research is needed on the aging of organic particles through aqueous phase processes in order to understand how the conditions of the liquid phase affects the formation of carboxylic compounds, the development of oligomers and the associated chemical mechanisms.

\section{Supplementary material related to this article is available online at: http://www.atmos-chem-phys.net/12/ 5879/2012/acp-12-5879-2012-supplement.pdf.}

Acknowledgements. This study was funded by INTROP (ESF), EUROCHAMP, Réseau ERICHE and the Provence-Alpes-Côted'Azur Region, INSU-LEFE-CHAT, the ANR-blanc (project CUMULUS), as well as the Swiss National Science Foundation. 
PFD received postdoctoral support from the US NSF (IRFP: 0701013). The authors thank Rafal Strekowski for his very kind help for the instruments shipping from the Aix-Marseille University to the Paul Scherrer Institute.

Edited by: V. F. McNeill

\section{References}

Aiken, A. C., DeCarlo, P. F., Kroll, J. H., Worsnop, D. R., Huffman, J. A., Docherty, K., Ulbrich, I. M., Mohr, C., Kimmel, J. R., Sueper, D., Zhang, Q., Sun, Y., Trimborn, A., Northway, M., Ziemann, P. J., Canagaratna, M. R., Onasch, T. B., Alfarra, R., Prevot, A. S. H., Dommen, J., Duplissy, J., Metzger, A., Baltensperger, U., and Jimenez, J. L.: O/C and OM/OC ratios of primary, secondary, and ambient organic aerosols with high resolution time-of-flight aerosol mass spectrometry. Environ, Sci. Technol., 42, 4478-4485, doi:10.1021/es703009q, 2008.

Altieri, K. E., Carlton, A. G., Lim, H. J., Turpin, B. J., and Seitzinger, S. P.: Evidence for oligomer formation in clouds: reactions of isoprene oxidation products, Environ. Sci. Technol., 40, 4956-4960, 2006.

Altieri, K. E., Seitzinger, S. P., Carlton, A. G., Turpin, B. J., Klein, G. C., and Marshall, A. G.: Oligomers formed through in-cloud methylglyoxal reactions: Chemical composition, properties, and mechanisms investigated by ultra-high resolution FT-ICR mass spectrometry, Atmos. Environ., 42, 1476-1490, 2008.

Anastasio, C. and McGregor, K. G.: Chemistry of fog waters in California's Central Valley. 1. In situ photoformation of hydroxyl radical and singlet molecular oxygen, Atmos. Environ., 35, 1079-1089, 2001.

Bateman, A. P., Nizkorodov, S. A., Laskinb, J., and Laskinc, A: Photolytic processing of secondary organic aerosols dissolved in cloud droplets, Phys. Chem. Chem. Phys., 13, 12199-12212, 2011.

Carlton, A. G., Turpin, B. J., Lim, H., Altieri, K. E., and Seitzinger, S.: Link between isoprene and secondary organic aerosol (SOA): pyruvic acid oxidation yields low volatility organic acids in clouds, Geophys. Res. Lett., 33, L06822, doi:10.1029/2005GL025374, 2006.

Carlton, A. G., Turpin, B. J., Altieri, K. E., Seitzinger, S., Reff, A., Lim, H. J., and Ervens, B.: Atmospheric oxalic acid and SOA production from glyoxal: results of aqueous photooxidation experiments, Atmos. Environ., 41, 7588-7602, 2007.

Carlton, A. G., Wiedinmyer, C., and Kroll, J. H.: A review of Secondary Organic Aerosol (SOA) formation from isoprene, Atmos. Chem. Phys., 9, 4987-5005, doi:10.5194/acp-9-4987-2009, 2009.

Chang, R. Y.-W., Slowik, J. G., Shantz, N. C., Vlasenko, A., Liggio, J., Sjostedt, S. J., Leaitch, W. R., and Abbatt, J. P. D.: The hygroscopicity parameter $(\kappa)$ of ambient organic aerosol at a field site subject to biogenic and anthropogenic influences: relationship to degree of aerosol oxidation, Atmos. Chem. Phys., 10, 5047-5064, doi:10.5194/acp-10-5047-2010, 2010.

Chhabra, P. S., Ng, N. L., Canagaratna, M. R., Corrigan, A. L., Russell, L. M., Worsnop, D. R., Flagan, R. C., and Seinfeld, J. H.: Elemental composition and oxidation of chamber organic aerosol, Atmos. Chem. Phys., 11, 8827-8845, doi:10.5194/acp-11-88272011, 2011.
Claeys, M., Graham, B., Vas, G., Wang, W., Vermeylen, R., Pashynska, V., Cafmeyer, J., Guyon, P., Andreae, M. O., Artaxo, P., and Maenhaut, W.: Formation of secondary organic aerosols through photooxidation of isoprene, Science, 303, 1173-1176, 2004a.

Claeys, M., Wang, W., Ion, A. C., Kourtchev, I., Gelencser, A., and Maenhaut, W.: Formation of secondary organic aerosols from isoprene and its gas-phase oxidation products through reaction with hydrogen peroxide, Atmos. Environ., 38, 4093-4098, 2004b.

DeCarlo, P. F., Kimmel, J. R., Trimborn, A., and Northway, M. J.: Field-deployable, high-resolution, time-of-flight aerosol mass spectrometer, Anal. Chem., 78, 8281-8289, 2006.

Dommen, J., Metzger, A., Duplissy, J., Kalberer, M., Alfarra, M. R., Gascho, A., Weingartner, E., Prevot, A. S. H., Verheggen, B., and Baltensperger, U.: Laboratory observation of oligomers in the aerosol from isoprene/ $\mathrm{NO}_{\mathrm{x}}$ photooxidation, Geophys. Res. Lett., 33, L13805, doi:10.1029/2006GL026523, 2006.

Duplissy, J., DeCarlo, P. F., Dommen, J., Alfarra, M. R., Metzger, A., Barmpadimos, I., Prevot, A. S. H., Weingartner, E., Tritscher, T., Gysel, M., Aiken, A. C., Jimenez, J. L., Canagaratna, M. R., Worsnop, D. R., Collins, D. R., Tomlinson, J., and Baltensperger, U.: Relating hygroscopicity and composition of organic aerosol particulate matter, Atmos. Chem. Phys., 11, 11551165, doi:10.5194/acp-11-1155-2011, 2011.

Edney, E. O., Kleindienst, T. E., Jaoui, M., Lewandowski, M., Offenberg, J. H., Wang, W., and Claeys, M.: Formation of 2-methyl tetrols and 2-methylglyceric acid in secondary organic aerosol from laboratory irradiated isoprene/ $\mathrm{NO}_{\mathrm{X}} / \mathrm{SO}_{2} /$ air mixtures and their detection in ambient $\mathrm{PM}_{2.5}$ samples collected in the eastern United States, Atmos. Environ., 39, 5281-5289, 2005.

El Haddad, I., Yao Liu, Nieto-Gligorovski, L., Michaud, V., Temime-Roussel, B., Quivet, E., Marchand, N., Sellegri, K., and Monod, A.: In-cloud processes of methacrolein under simulated conditions - Part 2: Formation of secondary organic aerosol, Atmos. Chem. Phys., 9, 5107-5117, doi:10.5194/acp-9-5107-2009, 2009.

Ervens, B., Turpin, B. J., and Weber, R. J.: Secondary organic aerosol formation in cloud droplets and aqueous particles (aqSOA): a review of laboratory, field and model studies, Atmos. Chem. Phys., 11, 11069-11102, doi:10.5194/acp-1111069-2011, 2011.

Eyglunent, G., Le Person, A., Dron, J., Monod, A., Voisin, D., Mellouki, A., Marchand, N., and Wortham, H.: Simple and reversible transformation of an APCI/MS/MS into an aerosol mass spectrometer: development and characterization of a new inlet, Aerosol Sci. Technol., 42, 182-193, 2008.

Guzmán, M. I., Colussi, A. I., and Hoffmann, M. R.: Photoinduced oligomerization of aqueous pyruvic acid, J. Phys. Chem. A, 110, 3619-3626, 2006.

Gysel, M., McFiggans, G. B., and Coe, H.: Inversion of tandem differential mobility analyser (TDMA) measurements, J. Aerosol Sci., 40, 134-151, 2009.

Hallquist, M., Wenger, J. C., Baltensperger, U., Rudich, Y., Simpson, D., Claeys, M., Dommen, J., Donahue, N. M., George, C., Goldstein, A. H., Hamilton, J. F., Herrmann, H., Hoffmann, T., Iinuma, Y., Jang, M., Jenkin, M. E., Jimenez, J. L., Kiendler-Scharr, A., Maenhaut, W., McFiggans, G., Mentel, Th. F., Monod, A., Prévôt, A. S. H., Seinfeld, J. H., Surratt, J. D., Szmigielski, R., and Wildt, J.: The formation, properties and 
impact of secondary organic aerosol: current and emerging issues, Atmos. Chem. Phys., 9, 5155-5236, doi:10.5194/acp-95155-2009, 2009.

Healy, R. M., Wenger, J. C., Metzger, A., Duplissy, J., Kalberer, M., and Dommen, J.: Gas/particle partitioning of carbonyls in the photooxidation of isoprene and 1,3,5-trimethylbenzene, Atmos. Chem. Phys., 8, 3215-3230, doi:10.5194/acp-8-3215-2008, 2008.

Herrmann, H., Hoffmann, D., Schaefer, T., Bräuer, P., and Tilgner, A.: Tropospheric aqueous phase free radical chemistry: Radical sources, spectra, reaction kinetics and prediction tools, Chem. Phys. Chem., 11, 3796-3822, 2010.

Hua, W., Chen, Z. M., Jie, C. Y., Kondo, Y., Hofzumahaus, A., Takegawa, N., Chang, C. C., Lu, K. D., Miyazaki, Y., Kita, K., Wang, H. L., Zhang, Y. H., and Hu, M.: Atmospheric hydrogen peroxide and organic hydroperoxides during PRIDE-PRD'06, China: their concentration, formation mechanism and contribution to secondary aerosols, Atmos. Chem. Phys., 8, 6755-6773, doi:10.5194/acp-8-6755-2008, 2008.

Jimenez, J. L., Canagaratna, M. R., Donahue, N. M., Prevot, A. S., Zhang, Q., Kroll, J. H., DeCarlo, P. F., Allan, J. D., Coe, H., Ng, N. L., Aiken, A. C., Docherty, K. S., Ulbrich, I. M., Grieshop, A. P., Robinson, A. L., Duplissy, J., Smith, J. D., Wilson, K. R., Lanz, V. A., Hueglin, C., Sun, Y. L., Tian, J., Laaksonen, A., Raatikainen, T., Rautiainen, J., Vaattovaara, P., Ehn, M., Kulmala, M., Tomlinson, J. M., Collins, D. R., Cubison, M. J., Dunlea, E. J., Huffman, J. A., Onasch, T. B., Alfarra, M. R., Williams, P. I., Bower, K., Kondo, Y., Schneider, J., Drewnick, F., Borrmann, S., Weimer, S., Demerjian, K., Salcedo, D., Cottrell, L., Griffin, R., Takami, A., Miyoshi, T., Hatakeyama, S., Shimono, A., Sun, J. Y., Zhang, Y. M., Dzepina, K., Kimmel, J. R., Sueper, D., Jayne, J. T., Herndon, S. C., Trimborn, A. M., Williams, L. R., Wood, E. C., Middlebrook, A. M., Kolb, C. E., Baltensperger, U., and Worsnop, D. R.: Evolution of organic aerosols in the atmosphere, Science, 326, 1525-1529, 2009.

Kawamura, K. and Sakaguchi, F.: Molecular distributions of water soluble dicarboxylic acids in marine aerosols over the Pacific Ocean including tropics, J. Geophys. Res., 104, 3501-3509, 1999.

Lambe, A. T., Onasch, T. B., Massoli, P., Croasdale, D. R., Wright, J. P., Ahern, A. T., Williams, L. R., Worsnop, D. R., Brune, W. H., and Davidovits, P.: Laboratory studies of the chemical composition and cloud condensation nuclei $(\mathrm{CCN})$ activity of secondary organic aerosol (SOA) and oxidized primary organic aerosol (OPOA), Atmos. Chem. Phys., 11, 8913-8928, doi:10.5194/acp11-8913-2011, 2011.

Lee, A. K. Y., Herckes, P., Leaitch, W. R., Macdonald, A. M., and Abbatt, J. P. D.: Aqueous OH oxidation of ambient organic aerosol and cloud water organics: Formation of highly oxidized products, Geophys. Res. Lett., 38, L11805, doi:10.1029/2011g1047439, 2011.

Legrand, M. and Puxbaum, H.: Summary of the CARBOSOL project: Present and retrospective state of organic versus inorganic aerosol over Europe, J. Geophys. Res., 112, D23S01, doi:10.1029/2006JD008271, 2007.

Lin, Y.H ., Zhang, Z., Docherty, K. S., Zhang, H., Budisulistiorini, S. H., Rubitschun, C. L., Shaw, S. L., Knipping, E. M., Edgerton, E. S., Kleindienst, T. E., Gold, A., and Surratt, J. D.: Isoprene epoxydiols as precursors to secondary organic aerosol forma- tion: Acid-catalyzed reactive uptake studies with authentic compounds. Environ. Sci. Technol., 46, 250-258, 2012.

Liu, Y., El Haddad, I., Scarfogliero, M., Nieto-Gligorovski, L., Temime-Roussel, B., Quivet, E., Marchand, N., Picquet-Varrault, B., and Monod, A.: In-cloud processes of methacrolein under simulated conditions - Part 1: Aqueous phase photooxidation, Atmos. Chem. Phys., 9, 5093-5105, doi:10.5194/acp-9-50932009, 2009.

Liu, Y., El Zein, A., Siekmann, F., Salque, G., El Haddad, I., Temime-Roussel, B., Voisin, D., Thissen, R., and Monod, A.: Oligomer and SOA formation through atmospheric aqueous phase processing of methacrolein and methyl vinyl ketone, Atmos. Environ., 49, 123-129, 2012.

Marinoni, A., Laj, P., Sellegri, K., and Mailhot, G.: Cloud chemistry at the Puy de Dôme: variability and relationships with environmental factors, Atmos. Chem. Phys., 4, 715-728, doi:10.5194/acp-4-715-2004, 2004.

Massoli, P., Lambe, A. T., Ahern, A. T., Williams, L. R., Ehn, M., Mikkilä, J., Canagaratna, M. R., Brune, W. H., Onasch, T. B., Jayne, J. T., Petäjä, T., Kulmala, M., Laaksonen, A., Kolb, C. E., Davidovits, P., and Worsnop, D. R.: Relationship between aerosol oxidation level and hygroscopic properties of laboratory generated secondary organic aerosol (SOA) particles, Geophys. Res. Lett., 37, L24801, doi:10.1029/2010GL045258, 2010.

Monod, A., Poulain, L., Grubert, S., Voisin, D., and Wortham, H.: Kinetics of $\mathrm{OH}$-initiated oxidation of oxygenated organic compounds in the aqueous phase: new rate constants, structureactivity relationships and atmospheric implications, Atmos. Environ., 39, 7667-7688, 2005.

Monod, A., Chevallier, E., Durand-Jolibois, R., Doussin, J. F., Picquet-Varrault, B., and Carlier, P.: Photooxidation of methylhydroperoxide and ethylhydroperoxide in the aqueous phase under simulated cloud droplet conditions, Atmos. Environ., 41, 24122426, 2007.

Ng, N. L., Canagaratna, M. R., Zhang, Q., Jimenez, J. L., Tian, J., Ulbrich, I. M., Kroll, J. H., Docherty, K. S., Chhabra, P. S., Bahreini, R., Murphy, S. M., Seinfeld, J. H., Hildebrandt, L., Donahue, N. M., DeCarlo, P. F., Lanz, V. A., Prévôt, A. S. H., Dinar, E., Rudich, Y., and Worsnop, D. R.: Organic aerosol components observed in Northern Hemispheric datasets from Aerosol Mass Spectrometry, Atmos. Chem. Phys., 10, 46254641, doi:10.5194/acp-10-4625-2010, 2010.

Nguyen, T. B., Roach, P. J., Laskin, J., Laskin, A., and Nizkorodov, S. A.: Effect of humidity on the composition of isoprene photooxidation secondary organic aerosol, Atmos. Chem. Phys., 11, 6931-6944, doi:10.5194/acp-11-6931-2011, 2011.

Nguyen, T. B., Laskin, A., Laskin, J., and Nizkorodov, S. A.: Direct aqueous photochemistry of isoprene high- $\mathrm{NO}_{\mathrm{x}}$ secondary organic aerosol, Chem. Phys. Phys. Chem., 14, 9702-9714, doi:10.1039/c2cp40944e, 2012.

Orlovic-Leko, P., Plavsic, M., Bura-Nakic, E., Kozarac, Z., and Cosovic, B.: Organic matter in the bulk precipitations in Zagreb and Sibenik, Croatia, Atmos. Environ., 43, 805-811, 2009.

Ortiz-Montalvo, D. L., Lim, Y. B., Perri, M. J., Seitzinger, S. P., and Turpin, B. J.: Volatility and Yield of Glycolaldehyde SOA Formed through Aqueous Photochemistry and Droplet Evaporation, Aerosol Sci. Technol., 46, 1002-1014, 2012.

Paulsen, D., Dommen, J., Kalberer, M., Prévôt, A. S. H., Richter, R., Sax, M., Steinbacher, M., Weingartner, E., and Baltensperger, 
U.: Secondary organic aerosol formation by irradiation of 1,3,5trimethylbenzene- $\mathrm{NO}_{\mathrm{x}}-\mathrm{H}_{2} \mathrm{O}$ in a new reaction chamber for atmospheric chemistry and physics, Environ. Sci. Technol., 39, 2668-2678, 2005.

Paulsen, D., Weingartner, E., Alfarra, M. R., and Baltensperger, U.: Volatility measurements of photochemically and nebulizer generated organic aerosol particles, J. Aerosol Sci., 37, 1025-1051, 2006.

Petters, M. D. and Kreidenweis, S. M.: A single parameter representation of hygroscopic growth and cloud condensation nucleus activity, Atmos. Chem. Phys., 7, 1961-1971, doi:10.5194/acp-71961-2007, 2007.

Perri, M. J., Seitzinger, S. P., and Turpin, B. J.: Secondary organic aerosol production from aqueous photooxidation of glycolaldehyde: laboratory experiments, Atmos. Environ., 43, 1487-1497, 2009.

Rudich, Y., Donahue, M. N., and Mentel, F. T.: Aging of organic aerosol: bridging the gap between laboratory and field studies, Annu. Rev. Chem., 58, 321-352, 2007.

Sato, K.: Detection of nitrooxypolyols in secondary organic aerosol formed from the photooxidation of conjugated dienes under high- $\mathrm{NO}_{\mathrm{x}}$ conditions, Atmos. Environ., 42, 6851-6861, 2008.

Silva Santos, L., Dalmazio, I., Eberlin, M. N., Claeys, M., and Augusti, R.: Mimicking the atmospheric OH-radical-mediated photooxidation of isoprene: formation of cloud-condensation nuclei polyols monitored by electrospray ionization mass spectrometry, Rapid Commun. Mass Sp., 20, 2104-2108, 2006.

Sorooshian, A., Varutbangkul, V., Brechtel, F. J., Ervens, B., Feingold, G., Bahreini, R., Murphy, S. M., Holloway, J. S., Atlas, E. L., Buzorius, G., Jonsson, H., Flagan, R. C., and Seinfeld, J. H.: Oxalic acid in clear and cloudy atmospheres: Analysis of data from the International Consortium for Atmospheric Research on Transport and Transformation 2004, J. Geophys. Res., 111, D23S45, doi:10.1029/2005JD006880, 2006.

Sorooshian, A., Lu, M.-L., Brechtel, F. J., Jonsson, H., Feingold, G., Flagan, R. C., and Seinfeld, J. H.: On the source of organic acid aerosol layers above clouds, Environ. Sci. Technol., 41, 46474654, 2007.

Sun, Y. L., Zhang, Q., Anastasio, C., and Sun, J.: Insights into secondary organic aerosol formed via aqueous-phase reactions of phenolic compounds based on high resolution mass spectrometry, Atmos. Chem. Phys., 10, 4809-4822, doi:10.5194/acp-104809-2010, 2010.

Surratt, J. D., Murphy, S. M., Kroll, J. H., Ng, N. L., Hildebrandt, L., Sorooshian, A., Szmigielski, R., Vermeylen, R., Maenhaut, W., Claeys, M., Flagan, R. C., and Seinfeld, J. H.: Chemical composition of secondary organic aerosol formed from the photooxidation of isoprene, J. Phys. Chem. A, 110, 9665-9690, 2006.
Surratt, J. D., Chan, A. W. H., Eddingsaas, N. C., Chan, M., Loza, C. L., Kwan, A. J., Hersey, S. P., Flagan, R. C., Wennberg, P. O., and Seinfeld, J. H.: Reactive intermediates revealed in secondary organic aerosol formation from isoprene, P. Natl Acad. Sci., 107, 6640-6645, 2010.

Szmigielski, R., Surratt, J. D., Vermeylen, R., Szmigielska, K., Kroll, J. H., Ng, N. L., Murphy, S. M., Sorooshian, A., Seinfeld, J. H., and Claeys, M.: Characterization of 2-methylglyceric acid oligomers in secondary organic aerosol from the photooxidation of isoprene using trimethylsilylation and gas chromatography/ion trap mass spectrometry, J. Mass Spectrom., 42, 101116, 2007.

Tan, Y., Perri, M. J., Seitzinger, S. P., and Turpin, B. J.: Effects of precursor concentration and acidic sulfate in aqueous glyoxal$\mathrm{OH}$ radical oxidation and implications for secondary organic aerosol, Environ. Sci. Technol., 43, 8105-8112, 2009.

Tan, Y., Carlton, G. A., Seitzinger, S. P., and Turpin, B. J.: SOA from methylglyoxal in clouds and wet aerosols: measurement and prediction of key products, Atmos. Environ., 44, 5218-5226, 2010.

Tan, Y., Lim, Y. B., Altieri, K. E., Seitzinger, S. P., and Turpin, B. J.: Mechanisms leading to oligomers and SOA through aqueous photooxidation: insights from $\mathrm{OH}$ radical oxidation of acetic acid and methylglyoxal, Atmos. Chem. Phys., 12, 801-813, doi:10.5194/acp-12-801-2012, 2012.

Tritscher, T., Dommen, J., DeCarlo, P. F., Gysel, M., Barmet, P. B., Praplan, A. P., Weingartner, E., Prévôt, A. S. H., Riipinen, I., Donahue, N. M., and Baltensperger, U.: Volatility and hygroscopicity of aging secondary organic aerosol in a smog chamber, Atmos. Chem. Phys., 11, 11477-11496, doi:10.5194/acp11-11477-2011, 2011.

Valorso, R., Aumont, B., Camredon, M., Raventos-Duran, T., Mouchel-Vallon, C., Ng, N. L., Seinfeld, J. H., Lee-Taylor, J., and Madronich, S.: Explicit modelling of SOA formation from $\alpha$-pinene photooxidation: sensitivity to vapour pressure estimation, Atmos. Chem. Phys., 11, 6895-6910, doi:10.5194/acp-116895-2011, 2011.

Zhang, X., Chen, Z. M., and Zhao, Y.: Laboratory simulation for the aqueous $\mathrm{OH}$-oxidation of methyl vinyl ketone and methacrolein: significance to the in-cloud SOA production, Atmos. Chem. Phys., 10, 9551-9561, doi:10.5194/acp-10-9551-2010, 2010. 